Article

\title{
New Antimicrobial Bromotyrosine Analogues from the Sponge Pseudoceratina purpurea and Its Predator Tylodina corticalis
}

\author{
Michael P. Gotsbacher and Peter Karuso * \\ Department of Chemistry \& Biomolecular Sciences, Macquarie University, Sydney, NSW 2109, \\ Australia; E-Mail: michael.gotsbacher@sydney.edu.au \\ * Author to whom correspondence should be addressed; E-Mail: peter.karuso@mq.edu.au; \\ Tel.: +61-2-9850-8290; Fax: +61-2-9850-8313.
}

Academic Editor: Orazio Taglialatela-Scafati

Received: 9 January 2015 / Accepted: 4 March 2015 / Published: 16 March 2015

\begin{abstract}
Bioassay-guided fractionation of extracts from temperate Australian collections of the marine sponge Pseudoceratina purpurea resulted in the isolation and characterisation of two new and six known bromotyrosine-derived alkaloids with antibiotic activity. Surprisingly, a single specimen of the mollusc Tylodina corticalis, which was collected while feeding on P. purpurea, contained only a few of the compounds found in the sponge suggesting selective accumulation and chemical modification of sponge metabolites.
\end{abstract}

Keywords: alkaloid; bromotyrosine; Pseudoceratina; sponge; Tylodina; antibiotics; marine natural products

\section{Introduction}

Sponges of the order Verongida are unique in the Demospongiae as the only group that contains alkaloids derived from bromotyrosine and sterols of the aplystane type; these are distinct chemotaxonomic markers for all the verongid genera [1-3]. The alkaloids have been reported to have antimicrobial [4-7], antifungal [8,9], cytotoxic [10-21], and antimalarial [22-24] activity for example and many have unique modes of action. Consequently, verongid sponges have no natural predators other than a few specialised molluscs such as nudibranchs [25].

In our continuing effort to isolate and identify new drug candidates from marine sponges [26] we screened temperate water sponges for antimicrobial and herbicidal activity. This revealed that the ethyl acetate partition of the ethanolic extract of Pseudoceratina purpurea (Carter 1880) displayed selective 
activity against Staphylococcus aureus $(35 \mathrm{~mm}$ zone of inhibition in a disc diffusion assay with no activity against $P$. aeruginosa). This sponge has previously been reported to be a rich source of bromotyrosine-derived alkaloids with wide ranges of biological activity [8,12,16,27-35]. However, temperate Australian specimens of this sponge have not previously been investigated and it is a characteristic of this species that different alkaloid profiles have been found from sponges collected at different locations.

In addition we were also encouraged to investigate the natural products of this sponge because we observed, and collected, a single specimen of the opisthobranch Tylodina corticalis (Tate, 1889) feeding on this sponge. As Tylodina is a partially shelled mollusc it would be interesting to determine if this mollusc accumulates defensive chemicals from its diet, lending weight to the theory that chemical defence is a pre-adaptation to loss of the protective shell found in most molluscs [25,36]. Tylodina corticalis has not previously been chemically investigated, but Proksch et al. have published their work on Tylodina perversa from the Mediterranean [5,37-39]. In their study, they found that T. perversa, fed on a diet of Aplysina aerophoba sequestering uranidine, isofistularin-3, aerophobin 1, aerophobin 2, and aplysinamisin-1. Whereas aerophobin 2 and isofistularin-3 made up about one third of the total alkaloids each in the sponge, aerophobin 2 constituted $\sim 70 \%$ of the alkaloids found in the mantles, mucus, and egg masses of $T$. perversa, indicating selective sequestration by the mollusc. Another $20 \%$ of the alkaloids found in T. perversa was attributed to aerothionin, which was not detected in the prey sponge suggesting that this compound may have come from a previous diet of a related sponge (e.g., A. cavernicola). Several species of Aplysina have been reported to contain high concentrations of aerothionin [13,40-43].

Herein we report the identification of 16 bromotyrosine alkaloids from Pseudoceratina purpurea and Tylodina corticalis by high resolution LC-MS/UV-Vis spectroscopy. Eight of these were isolated preparatively and subject to 2D NMR analysis, revealing two to be new compounds.

\section{Results and Discussion}

The ethanol extracts of both the sponge and mollusc appeared as yellow solutions, which quickly turned dark-purple when exposed to air. This suggested the presence of the well-known verongid sponge pigment uranidine [44]. As the crude extract showed selective activity against $S$. aureus (Supplementary Information), activity against this organism was used for the bioassay-guided isolation. The ethyl acetate partition of the ethanolic extract of $P$. purpurea was subject to gel filtration (Sephadex LH-20) and fractions (9-22), with activity against S. aureus, were combined. A similar extraction of $T$. corticalis yielded only $12 \mathrm{mg}$ in the ethyl acetate partition so this was not subject to gel filtration but analysed without further fractionation. Comparison of the two extracts (Figure 1A,B) suggested a similar pattern of metabolites eluting around $20 \mathrm{~min}$ but the $T$. corticalis extract was much simpler in composition. However, more careful examination of this region (Figure 1C,D) showed that even the major peaks of the sponge and mollusc did not overlap exactly. Using nanospray HRMS in combination with UV-Vis spectra (Figure S1; Supplementary Information) allowed us to tentatively identify most of the compounds from both organisms (Table 1). While both organisms contained bromotyrosine-derived alkaloids, very little overlap in secondary metabolites between the two organisms 
existed (highlighted in grey in Table 1), which was surprising considering there was evidence of extensive feeding by $T$. corticalis on the sponge sample that was collected and extracted in this work.
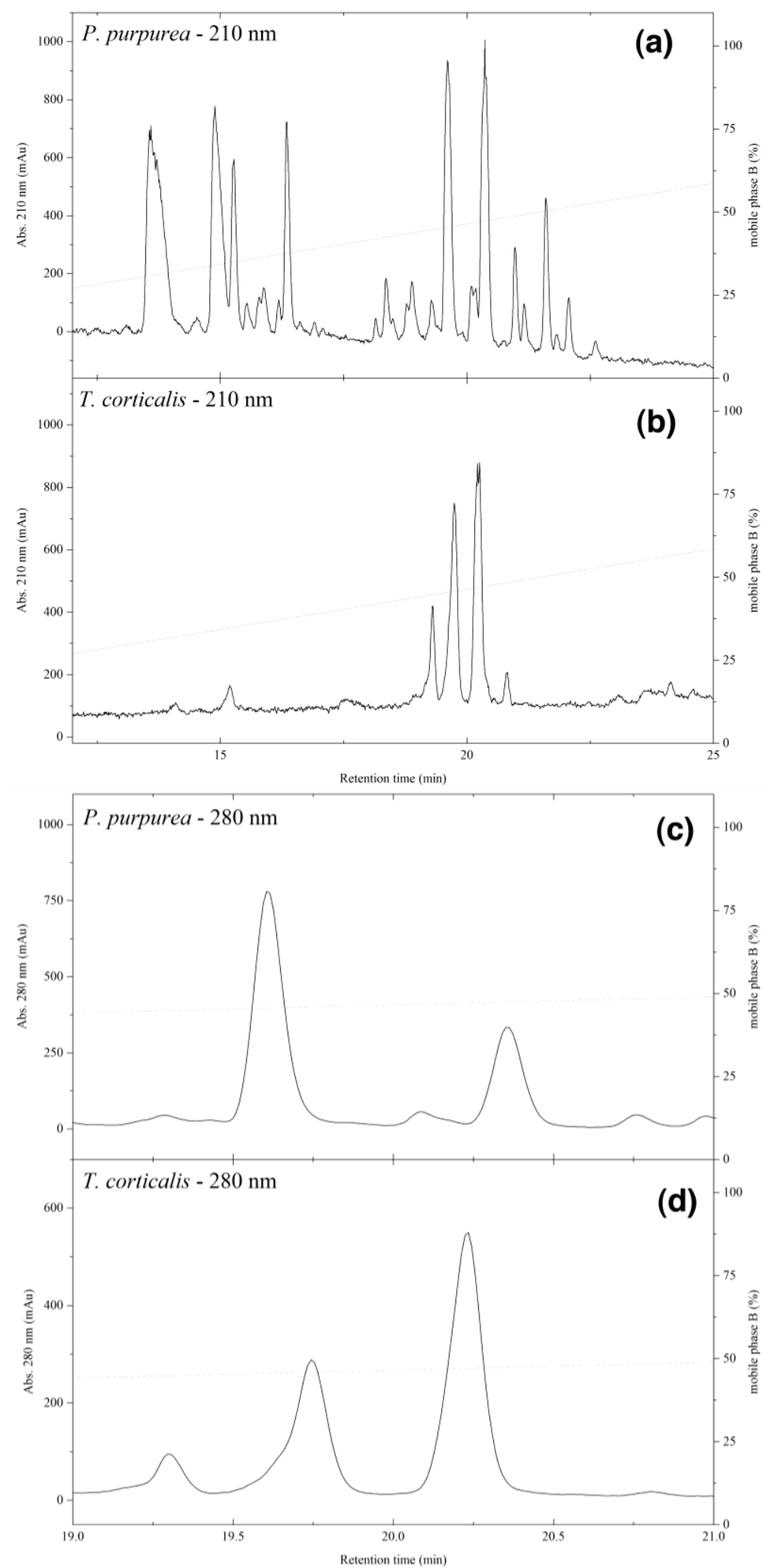

Figure 1. Low resolution-LCMS chromatograms $\left(\lambda_{\max } 210 \mathrm{~nm}\right)$ of ethyl acetate partitions of P. purpurea (A) and T. corticalis (B); Panels (C) and (D) are expansions of the 19-21 min regions $(\lambda \max 280 \mathrm{~nm})$. 
Table 1. Low and high resolution LC-MS data from extracts of P. purpurea and T. corticalis.

\begin{tabular}{|c|c|c|c|c|c|c|c|c|}
\hline $\mathbf{R}_{\mathbf{T}}(\min )^{\mathbf{a}}$ & $\lambda_{\max }(\mathbf{n m})$ & $\mathbf{B r}_{x}{ }^{\mathbf{b}}$ & $\mathrm{HR} m / z$ & Molecular Formula $[\mathbf{M}+\mathbf{H}]^{+}$ & $\Delta$ ppm & $P$. purpurea ${ }^{\mathrm{c}}$ & T. corticalis $^{\mathrm{c}}$ & Compound $^{\mathrm{c}}$ \\
\hline $13.7-14.2$ & 226,286 & 2 & $\begin{array}{c}489.9717, \\
491.9689,493.9665\end{array}$ & $\mathrm{C}_{15} \mathrm{H}_{18} \mathrm{Br}_{2} \mathrm{~N}_{5} \mathrm{O}_{4}$ & $-0.306,-1.059,-1.413$ & +++ & + & pseudoceratinin A (3) \\
\hline 14.67 & 232,286 & 2 & $\begin{array}{c}494.0030, \\
496.0004,497.9983\end{array}$ & $\mathrm{C}_{15} \mathrm{H}_{22} \mathrm{Br}_{2} \mathrm{~N}_{5} \mathrm{O}_{4}$ & $-0.306,-0.859,-0.913$ & + & + & purealidin L (10) \\
\hline $15.1-15.4$ & 228,285 & 2 & $\begin{array}{c}503.9878, \\
505.9848,507.9824\end{array}$ & $\mathrm{C}_{16} \mathrm{H}_{20} \mathrm{Br}_{2} \mathrm{~N}_{5} \mathrm{O}_{4}$ & $+0.144,-0.809,-1.163$ & +++ & ++ & aerophobin 2 (4) \\
\hline 15.41 & $\begin{array}{c}234,276, \\
340\end{array}$ & 2 & $\begin{array}{c}680.9950, \\
682.9920,684.9897\end{array}$ & $\mathrm{C}_{24} \mathrm{H}_{23} \mathrm{Br}_{2} \mathrm{~N}_{6} \mathrm{O}_{8}$ & $+0.937,+0.183,-0.070$ & + & & ceratinadin B (11) \\
\hline 16.35 & $\begin{array}{c}234,276 \\
337\end{array}$ & 2 & $\begin{array}{c}695.0095, \\
697.0067,699.0046\end{array}$ & $\mathrm{C}_{25} \mathrm{H}_{25} \mathrm{Br}_{2} \mathrm{~N}_{6} \mathrm{O}_{8}$ & $-0.013,-0.767,-0.820$ & ++ & & new (ceratinadin D) (1) \\
\hline 18.48 & 209,286 & 2 & $\begin{array}{c}489.9722, \\
491.9692,493.9668\end{array}$ & $\mathrm{C}_{15} \mathrm{H}_{18} \mathrm{~N}_{5} \mathrm{O}_{4} \mathrm{Br}_{2}$ & $+0.194,-0.759,-1.113$ & + & & purealidin M (12) \\
\hline 19.00 & 209,286 & 2 & $\begin{array}{c}503.9878, \\
505.9857,507.9835\end{array}$ & $\mathrm{C}_{16} \mathrm{H}_{20} \mathrm{Br}_{2} \mathrm{~N}_{5} \mathrm{O}_{4}$ & $+0.144,+0.091,-0.063$ & + & & aerophobin 2 isomer \\
\hline 19.41 & 210 & 0 & 293.2335 & - & - & + & ++ & $\begin{array}{l}\text { C18 fatty acid } \\
\text { methyl ester? }\end{array}$ \\
\hline $19.3-19.8$ & 223,280 & 4 & $\begin{array}{c}\text { 713.8461, 715.8431, } \\
717.8400,719.8376, \\
721.8355 \\
\end{array}$ & $\mathrm{C}_{21} \mathrm{H}_{24} \mathrm{Br}_{4} \mathrm{~N}_{3} \mathrm{O}_{5}$ & $\begin{array}{c}+1.502,+0.749 \\
-0.305,-0.658,-0.711\end{array}$ & +++ & + & hexadellin A (4) \\
\hline 19.85 & 203,280 & 4 & $\begin{array}{c}741.8751, \\
743.8729,745.8709, \\
747.8689,749.8669 \\
\end{array}$ & $\mathrm{C}_{23} \mathrm{H}_{28} \mathrm{Br}_{4} \mathrm{~N}_{3} \mathrm{O}_{5}$ & $\begin{array}{c}-0.598,-0.751 \\
-0.705,-0.658,-0.611\end{array}$ & $\sim$ & +++ & $\begin{array}{l}\text { purealidin P (13) } \\
\quad \text { or Q (14) }\end{array}$ \\
\hline 20.08 & 210 & 0 & 293.2333 & - & - & $\sim$ & $\sim$ & $\begin{array}{l}\text { C18 fatty acid } \\
\text { methyl ester? }\end{array}$ \\
\hline
\end{tabular}


Table 1. Cont.

\begin{tabular}{|c|c|c|c|c|c|c|c|c|}
\hline $\mathbf{R}_{\mathbf{T}}(\mathbf{m i n})^{\mathbf{a}}$ & $\lambda_{\max }(\mathbf{n m})$ & $\mathbf{B r}_{x}^{\mathbf{b}}$ & $\mathrm{HR} m / z$ & Molecular Formula $[\mathbf{M}+\mathbf{H}]^{+}$ & $\Delta$ ppm & P. purpurea ${ }^{\mathrm{c}}$ & T. corticalis $^{\mathrm{c}}$ & Compound $^{\mathrm{c}}$ \\
\hline 20.13 & 203,280 & 4 & $\begin{array}{c}757.8720, \\
759.8688,761.8660, \\
763.8634,765.8616 \\
\end{array}$ & $\mathrm{C}_{23} \mathrm{H}_{28} \mathrm{Br}_{4} \mathrm{~N}_{3} \mathrm{O}_{6}$ & $\begin{array}{c}+1.388,+0.234 \\
-0.519,-1.073,-0.826\end{array}$ & & +++ & $\begin{array}{c}\text { purealidin } \mathrm{T}(\mathbf{1 5}) \text { or } \\
\text { purealidin P } N \text {-oxide (16) }\end{array}$ \\
\hline 20.30 & impure & 3 & $\begin{array}{c}633.9558,635.9530, \\
637.9503,639.9482\end{array}$ & $\mathrm{C}_{22} \mathrm{H}_{27} \mathrm{Br}_{3} \mathrm{~N}_{3} \mathrm{O}_{4}$ & $\begin{array}{l}+1.179,+0.426 \\
-0.227,-0.281\end{array}$ & + & & $\begin{array}{c}\text { aplysamine } 7 \text { (17), } \\
\text { purpurealidin H (18), } \\
\text { purpuramine I (19) or } \\
\text { purpuramine L (20) }\end{array}$ \\
\hline $20.47-20.53$ & 222,280 & 3 & $\begin{array}{c}647.9707,649.9673, \\
651.9644,653.9627\end{array}$ & $\mathrm{C}_{23} \mathrm{H}_{29} \mathrm{Br}_{3} \mathrm{~N}_{3} \mathrm{O}_{4}$ & $\begin{array}{l}+0.429,-0.924 \\
-1.777,-1.431\end{array}$ & +++ & + & aplysamine $2(6)$ \\
\hline 20.90 & 234,279 & 3 & $\begin{array}{c}663.9649,665.9630, \\
667.9609,669.9587 \\
\end{array}$ & $\mathrm{C}_{23} \mathrm{H}_{29} \mathrm{Br}_{3} \mathrm{~N}_{3} \mathrm{O}_{5}$ & $\begin{array}{l}-0.285,-0.139 \\
-0.192,-0.345\end{array}$ & & ++ & $\begin{array}{c}\text { purpuramine } \mathrm{J}(\mathbf{2 1}) \\
\text { (aplysamine } 2 \mathrm{~N} \text {-oxide) }\end{array}$ \\
\hline 20.98 & 210,278 & 3 & $\begin{array}{c}619.9397,621.9368, \\
623.9340,625.9320\end{array}$ & $\mathrm{C}_{21} \mathrm{H}_{25} \mathrm{Br}_{3} \mathrm{~N}_{3} \mathrm{O}_{4}$ & $\begin{array}{l}+0.729,-0.124 \\
-0.877,-0.831 \\
\end{array}$ & ++ & & $\begin{array}{c}\text { 16-debromo-aplysamine } \\
4(7)\end{array}$ \\
\hline 21.71 & 209,278 & 4 & $\begin{array}{c}697.8505, \\
699.8476,701.8446, \\
703.8420,705.8401 \\
\end{array}$ & $\mathrm{C}_{21} \mathrm{H}_{24} \mathrm{Br}_{4} \mathrm{~N}_{3} \mathrm{O}_{4}$ & $\begin{array}{c}+1.017,+0.163 \\
-0.790,-1.343,-1.197\end{array}$ & ++ & & new (aplysamine 8) (2) \\
\hline 22.25 & 209,278 & 4 & $\begin{array}{c}879.8942, \\
881.8915,883.8894, \\
885.8871,887.8850 \\
\end{array}$ & $\mathrm{C}_{2} \mathrm{H}_{30} \mathrm{Br}_{4} \mathrm{~N}_{7} \mathrm{O}_{7}$ & $\begin{array}{c}+0.727,+0.073,+0.020 \\
-0.233,-0.287\end{array}$ & ++ & & purealine (8) \\
\hline 24.27 & $\begin{array}{c}240,308 \\
363\end{array}$ & 2 & $\begin{array}{c}404.9809,406.9787, \\
408.9765\end{array}$ & $\mathrm{C}_{14} \mathrm{H}_{19} \mathrm{Br}_{2} \mathrm{~N}_{2} \mathrm{O}_{2}$ & $+0.120,-0.033,-0.186$ & & + & new unknown \\
\hline
\end{tabular}

${ }^{a}$ Retention times from LR LCMS trace (Figure 1); ${ }^{\mathrm{b}}$ number of bromine atoms from LR-MS molecular ion isotopic pattern; ${ }^{\mathrm{c}}+++$; major metabolite, ++; medium abundance metabolite, +; minor metabolite; - no molecular formula was found and ; trace metabolite; ${ }^{\mathrm{d}}$ tentative assignment based on HR-MS and UV (see Figures 2 and 7); Grey indicates similarities between P. purpurea and T. corticalis. Italic indicates low accuracy for UV spectrum due to low sample concentration. Bold indicates new compounds. 
Preparative HPLC separation of the eight major compounds from the sponge confirmed the tentative structures assigned by HR LC-MS and UV-Vis and that two of the compounds (1 and 2) were new (Figure 2). The six known compounds were (-)-pseudoceratinine A (3) [45]; (+)-aerophobin 2 (4) [46]; (-)-hexadellin A (5) [47]; aplysamine 2 (6) [48]; 16-debromoaplysamine 4 (7) [49]; $(-)$-purealin (8) [50] (Figure 2) and their NMR spectral data matched those reported in the literature. The two new compounds were subject to full spectral analysis to determine their structure and stereochemistry.

Ceratinadin D (1) was obtained as an optically active solid $\left([\alpha]_{\mathrm{D}}^{20}+52\right)$ with UV maxima at 234 , 276 , and $337 \mathrm{~nm}$, suggesting the presence of a spiro-cyclohexadienyl-isoxazoline ( $\left.\lambda_{\max } 234,276 \mathrm{~nm}\right)$ and a uranidine moiety $\left(\lambda_{\max } 337 \mathrm{~nm}\right)$. The IR absorptions indicated the existence of $\mathrm{OH}$ and/or $\mathrm{NH}$ (3420, 3380, and $\left.3290 \mathrm{~cm}^{-1}\right)$ and an amide $\left(1677 \mathrm{~cm}^{-1}\right)$. The low resolution mass spectrum displayed an isotopic cluster $(694.95,696.95,699.00 \mathrm{amu}$ in ratio 1:2:1) suggesting two bromines were present. High resolution mass spectrometry suggested a molecular formula $\mathrm{C}_{25} \mathrm{H}_{2}{ }^{79} \mathrm{Br}_{2} \mathrm{~N}_{6} \mathrm{O}_{8}(0.013$ ppm error). These data matched reasonably well with those reported for (+)-ceratinadins A and B [9].
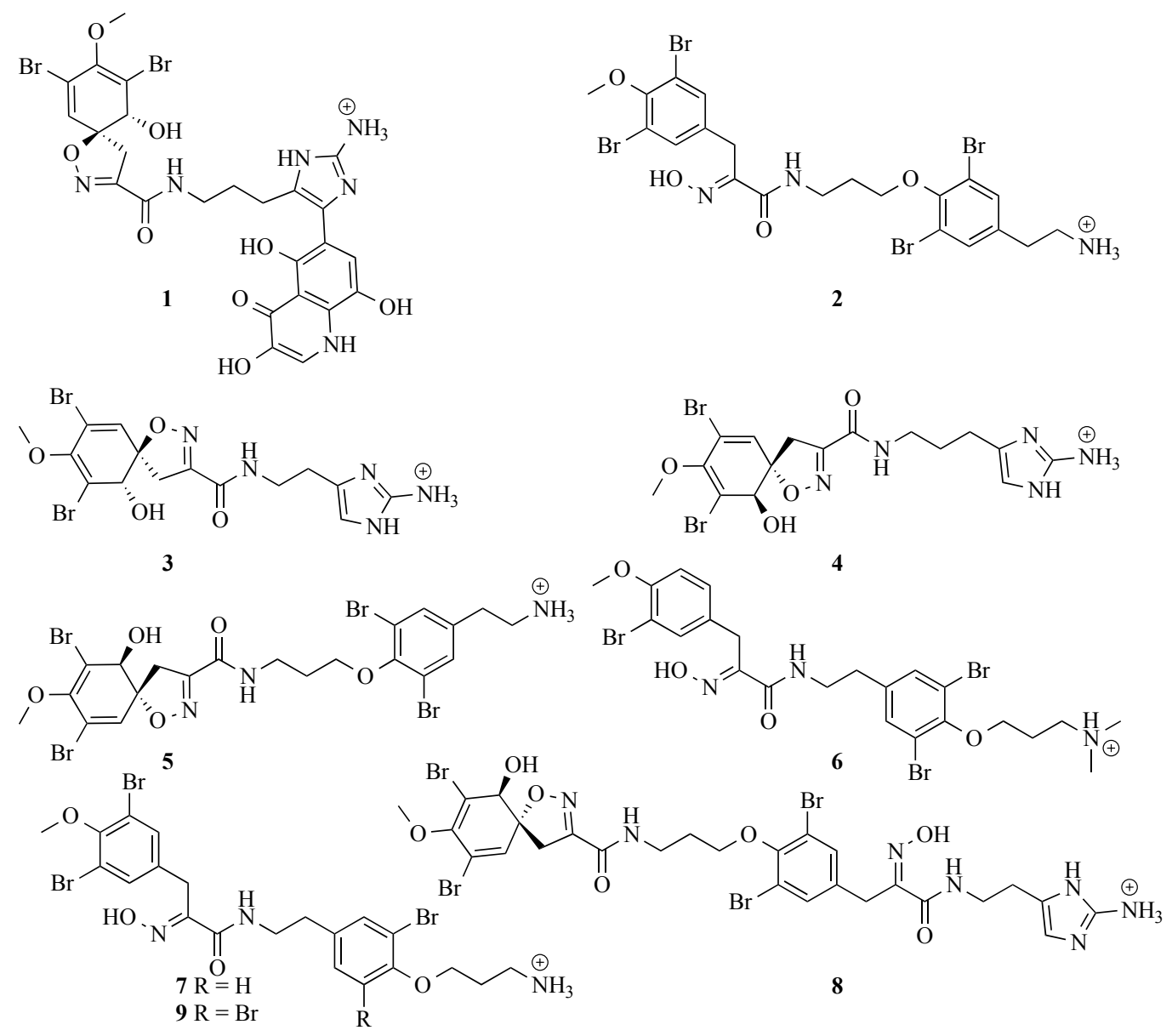

Figure 2. Bromotyrosine-alkaloids isolated from the marine sponge $P$. purpurea.

The ${ }^{13} \mathrm{C}$ NMR spectrum indicated the presence of 25 carbons (Table 2), one $O$-methyl ( $\left.\delta 59.7\right)$, four methylenes $(\delta 39.0,38.2,28.1,21.6)$, three $\mathrm{sp}^{2}$ methines $(\delta 131.2,124.2,113.7)$, one $\mathrm{sp}^{3}$ methine $(\delta 73.5), 13 \mathrm{sp}^{2}$ quaternaries $(\delta 154.5,149.6,147.6,146.6,139.9,137.4,128.9,122.4,120.9,117.8$, $113.1,112.6,103.2)$, one $\mathrm{sp}^{3}$ quaternary $(\delta 90.1)$ and two carbonyls $(\delta 173.2,158.9)$. 
Table 2. NMR (DMSO- $d_{6}, 600 \mathrm{MHz}$ ) data for new bromotyrosine compound (1).

\begin{tabular}{|c|c|c|c|c|c|}
\hline Position & $\boldsymbol{\delta}_{\mathbf{C}}$ & Type & $\delta_{\mathrm{H}}, \mathbf{m}(J$ in $\mathbf{H z})$ & COSY (H no.) & ${ }^{1} \mathrm{H}-{ }^{13} \mathrm{C}$ HMBC (C no.) \\
\hline 1 & 73.5 & $\mathrm{CH}$ & $3.90 \mathrm{~d}(7.7)$ & 9 & $3,4,5,6$ \\
\hline 2 & 120.9 & $\mathrm{C}$ & - & & \\
\hline 3 & 147.6 & $\mathrm{C}$ & - & & \\
\hline 4 & 113.1 & $\mathrm{C}$ & - & & \\
\hline 5 & 131.2 & $\mathrm{CH}$ & $6.54 \mathrm{~s}$ & 1 & $2,3,4,6(\mathrm{w})^{\mathrm{a}}, 10$ \\
\hline 6 & 90.1 & $\mathrm{C}$ & - & & \\
\hline 8 & 59.7 & $\mathrm{CH}_{3}$ & $3.63 \mathrm{~s}$ & & 3 \\
\hline 9 & - & $\mathrm{OH}$ & $6.36 \mathrm{~d}(7.7)$ & 1 & $1(\mathrm{w}), 4(\mathrm{w}), 6(\mathrm{w})$ \\
\hline 10 & 39.0 & $\mathrm{CH}_{2}$ & $3.59 \mathrm{~d}(3.6), 3.15 \mathrm{~d}(3.6)$ & 10 & $1,5,6,11$ \\
\hline 11 & 154.5 & $\mathrm{C}$ & - & & \\
\hline 14 & 158.9 & $\mathrm{C}$ & - & & \\
\hline 16 & - & $\mathrm{NH}$ & $8.51 \mathrm{t}(5.8)$ & 17 & 14 \\
\hline 17 & 38.2 & $\mathrm{CH}_{2}$ & $3.13 \mathrm{~m}$ & 18 & 18,19 \\
\hline 18 & 28.1 & $\mathrm{CH}_{2}$ & $1.73 \mathrm{~m}$ & 17,19 & 17,19 \\
\hline 19 & 21.6 & $\mathrm{CH}_{2}$ & $2.51 \mathrm{~m}$ & 18 & $18(\mathrm{w}), 20,24$ \\
\hline 20 & 122.4 & $\mathrm{C}$ & - & & \\
\hline 21 & - & NH & $11.93 \mathrm{bs}$ & 23 & $20(w)$ \\
\hline 22 & 146.6 & $\mathrm{C}$ & - & & \\
\hline 23 & - & NH & $12.15 \mathrm{bs}$ & 21 & - \\
\hline 24 & 117.8 & $\mathrm{C}$ & - & & \\
\hline 25 & - & $\mathrm{NH}_{2}$ & $7.28 \mathrm{bs}$ & & \\
\hline $1^{\prime}$ & - & $\mathrm{NH}$ & $11.76 \mathrm{~d}(6.4)$ & $2^{\prime}$ & $3^{\prime}, 5^{\prime}$ \\
\hline $2^{\prime}$ & 124.2 & $\mathrm{CH}$ & $7.64 \mathrm{~d}(6.4)$ & $1^{\prime}$ & $4^{\prime}, 10^{\prime}$ \\
\hline $3^{\prime}$ & 139.9 & $\mathrm{C}$ & - & & \\
\hline $4^{\prime}$ & 173.2 & $\mathrm{C}$ & - & & \\
\hline $5^{\prime}$ & 112.6 & $\mathrm{C}$ & - & & \\
\hline $6^{\prime}$ & 149.6 & $\mathrm{C}$ & - & & \\
\hline $7^{\prime}$ & 103.2 & $\mathrm{C}$ & - & & \\
\hline $8^{\prime}$ & 113.7 & $\mathrm{CH}$ & $6.83 \mathrm{~s}$ & & $24,6^{\prime}, 9^{\prime}, 10^{\prime}$ \\
\hline $9^{\prime}$ & 137.4 & $\mathrm{C}$ & - & & \\
\hline $10^{\prime}$ & 128.9 & $\mathrm{C}$ & - & & \\
\hline $11^{\prime}$ & - & $\mathrm{OH}$ & $8.93 \mathrm{bs}$ & & \\
\hline $12^{\prime}$ & - & $\mathrm{OH}$ & $14.3 \mathrm{bs}$ & & $5^{\prime}, 6^{\prime}(\mathrm{w})$ \\
\hline $13^{\prime}$ & - & $\mathrm{OH}$ & $10.25 \mathrm{bs}$ & & $10^{\prime}$ \\
\hline
\end{tabular}

${ }^{\mathrm{a}}(\mathrm{w})$ denotes a weak correlation.

Use of one and two-dimensional NMR data (Table 2) enabled the construction of four substructures (Figure 3). Inspection of ${ }^{1} \mathrm{H},{ }^{13} \mathrm{C}$, and ${ }^{1} \mathrm{H}-{ }^{1} \mathrm{H}$ COSY NMR spectra suggested that the following proton signals belonged to the same spin system: $\delta_{\mathrm{H}} 6.54$ ( $\mathrm{sp}^{2}$ methine), $\delta_{\mathrm{H}} 3.90\left(\mathrm{sp}^{3}\right.$ methine), $\delta_{\mathrm{H}} 3.63(\mathrm{OMe})$, and an $\mathrm{AB}$ system $\left(\delta_{\mathrm{H}} 3.59\right.$ and $\delta_{\mathrm{H}} 3.15$ each $\left.1 \mathrm{H}\right)$ characteristic of a spirocycloisoxazoline ring previously published from other verongid compounds [51]. HMBC correlations from $\mathrm{H}-5$ to $\mathrm{C}-1, \mathrm{C}-2$, C-3, H-8 to C-3, and H-10a/b to C-1, C-6, C-11 confirmed the 1-hydroxy-2,4-dibromo-3-methoxy-11carbonyl spirocyclohexadienyl isoxazole (substructure $\mathbf{A}$ ) and the connection between substructures $\mathbf{A}$ and $\mathbf{B}$ was obtained by an HMBC correlation from $\mathrm{H}-10 \mathrm{a} / \mathrm{b}$ to $\mathrm{C}-14$. 
The signal at $\delta_{\mathrm{H}} 8.51(\mathrm{NH})$ showed a coupling to $\delta_{\mathrm{H}} 3.13(\mathrm{H}-17)$ and an HMBC correlation to the amide carbonyl (C-14; $\delta 158.9)$. Further COSY correlations from $\mathrm{H}-17$ to $\mathrm{H}-18\left(\delta_{\mathrm{H}} 1.73\right)$, and in turn $\mathrm{H}-19\left(\delta_{\mathrm{H}} 2.51\right)$ supported the conclusion that substructure $\mathbf{B}$ was an amide unit connected to a propyl chain (c.f. an ethyl chain in ceratinadin A and B).

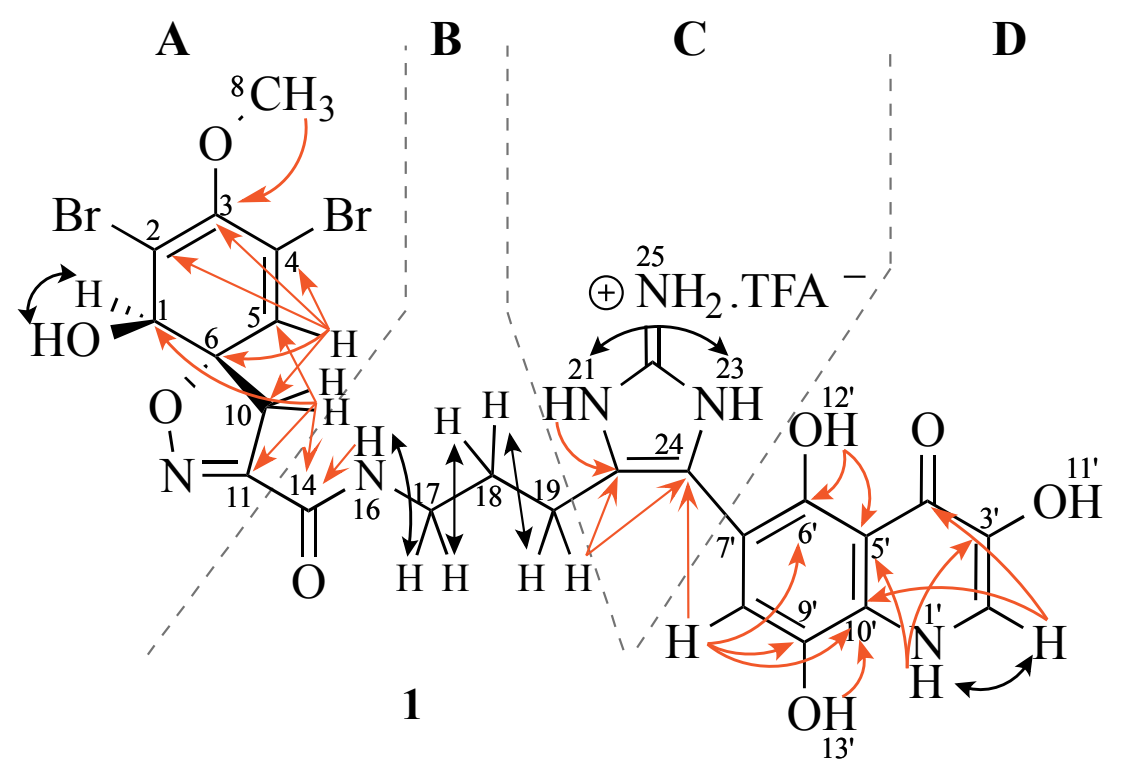

Figure 3. Structure and selected COSY (black) and HMBC (red) correlations of new bromotyrosine compound $\mathbf{1}$.

HMBC correlations between $\mathrm{H}-19$ and $\mathrm{C}-20$ and $\mathrm{C}-24$ (Figure 4) indicated that the $\mathrm{CH}_{2}$ at $\delta_{\mathrm{C}}$ $21.2 \mathrm{ppm}$ was connected to the imidazole ring. The w-COSY correlation between two broad singlets at $\delta_{\mathrm{H}} 11.93(\mathrm{~N}-21 \mathrm{H})$ and $\delta_{\mathrm{H}} 12.15(\mathrm{~N}-23 \mathrm{H})$, and the $2 \mathrm{H}$ singlet at $\delta_{\mathrm{H}} 7.77$ suggested the imidazole is present in the form of an imidazolium salt. The presence of a homohistamine unit is commonly observed in verongid metabolites [51] and was also found in other metabolites from this sponge. For example, aerophobin, pseudoceratinin A, and purealin show similar NMR data for this substructure and provided good evidence for unit $\mathbf{B} / \mathbf{C}$. Although there were no correlations to $\mathbf{C}-22$, a quaternary carbon at $\delta 146.6$ was observed, which matches literature values for 2-aminoimidazole. Because of resonance and long T1 relaxation times, it is common not to observe correlations with guanidine carbons.

The HMBC correlations in the trihydroxy quinolinone (uranidine) ring system $\left(\mathrm{H}-1^{\prime}\right.$ to $\mathrm{C}-2^{\prime}$ and C-10') matched those previously reported for 7-substituted 3,6,9-trihydroxy quinolinone [52]. In addition, $\mathrm{H}_{-} \mathrm{8}^{\prime}$ also showed a correlation to $\mathrm{C}-10^{\prime}$ (see Figure $4 \mathrm{~b}$ ), which could only be observed with 7-substitution (c.f. from $\mathrm{H}^{\prime}$ a ${ }^{4} J_{\mathrm{CH}}$ coupling would not be observable). If the uranidine moiety was attached at C-8'; ${ }^{3} J_{C H}$ couplings should be observed from $\mathrm{H}^{-} 7^{\prime}$ to $\mathrm{C}-9^{\prime}$ and C-5'. The site of attachment at the imidazole was clearly indicated by strong correlations between C-24 and H-19 and H-8' (Figure 4). Further evidence for the presence of unit $\mathbf{D}$ arose from ${ }^{1} \mathrm{H}-{ }^{1} \mathrm{H}$ coupling between $\mathrm{H}-2^{\prime}\left(\delta_{\mathrm{H}} 7.64, \mathrm{~d}\right.$, $J=5.8 \mathrm{~Hz})$ and $\mathrm{H}-1^{\prime}\left(\delta_{\mathrm{H}} 11.76, \mathrm{~d}, J=5.8 \mathrm{~Hz}\right)$. 

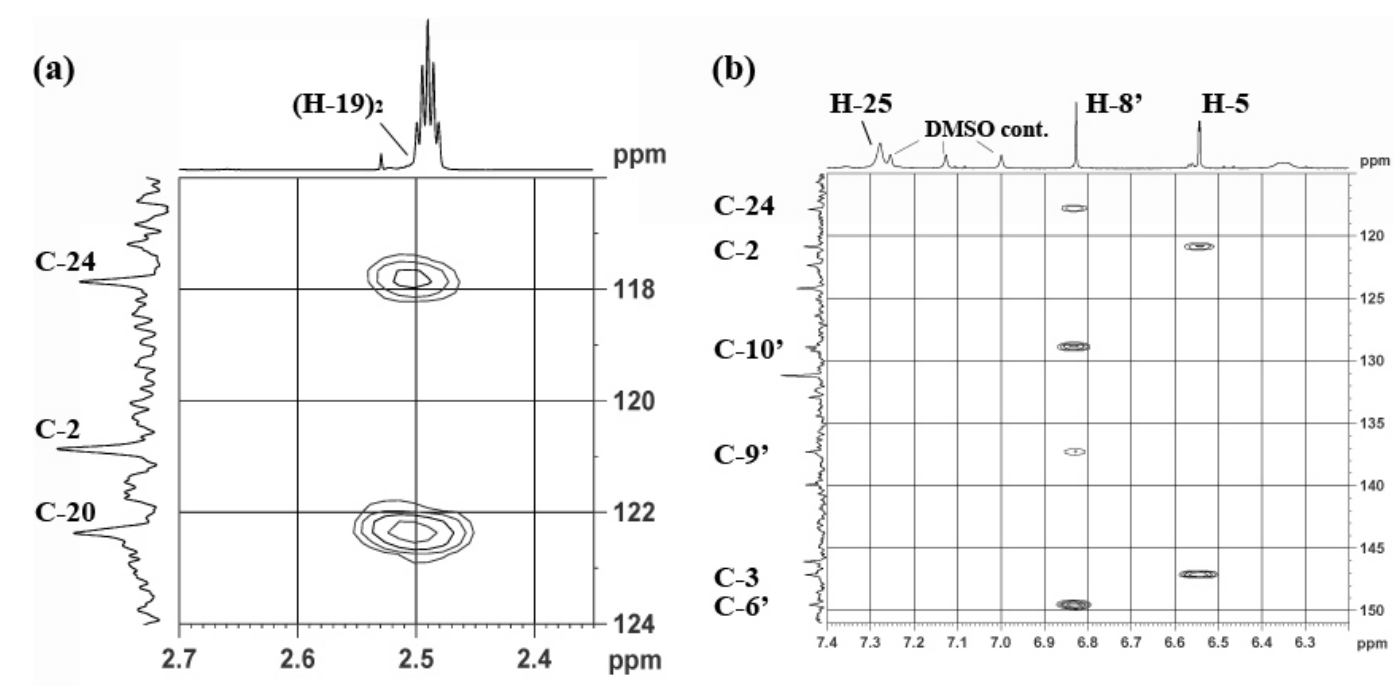

Figure 4. Selected HMBC correlations of 1: (a) from H-19 ( $\delta 2.51)$ to C-20 ( $\delta 122.4)$ and C-24 ( $\delta$ 117.8) of the imidazole moiety. H-19 lies under the large DMSO peak (2.49 ppm). (b) from H-8' $(\delta 6.83)^{3} J$ couplings to C-24 $(\delta 117.8)$ of the imidazole moiety, and to C-6' $(\delta 149.6), \mathrm{C}-10^{\prime}(\delta 128.9)$ and $\mathrm{a}^{2} J$ coupling to $\mathrm{C}-9^{\prime}(\delta 137.4)$ of the uranidine moiety.

The chemical shifts for subunits $\mathbf{A}, \mathbf{C}$ and $\mathbf{D}$ all aligned very well with those described for ceratinadin B [9], a compound similar to the one described here. However, ceratinadin B contains a histamine unit instead of homohistamine (subunit B) and thus a lower molecular weight. Due to the similarity of these two compounds, and with the other ceratinadins, we named this compound ceratinadin D. Finally, the specific rotation of $\mathbf{1}$ is very similar to that of ceratinadin B strongly suggesting the same absolute stereochemistry $(1 R, 6 S)$.

Aplysamine 8 (2) was a simple bromotyrosine derivative $\left(\lambda_{\max } 278 \mathrm{~nm}\right)$ with four bromines $(\mathrm{M}+\mathrm{H}$ pentet; $m / z 698$ (1), 700 (4), 702 (6), 704 (4), 706 (1)). The HRMS was consistent with a molecular formula $\mathrm{C}_{21} \mathrm{H}_{23} \mathrm{Br}_{4} \mathrm{~N}_{3} \mathrm{O}_{4}$ (Table 1). In addition, three characteristic bands in the infrared spectrum $\left(v_{\max } 3572,1672\right.$ and $1001 \mathrm{~cm}^{-1}$ ), confirmed the presence of an oxime.

These data suggested the compound was aplysamine 4 (9) [10]. However, comparison of the ${ }^{1} \mathrm{H}-\mathrm{NMR}$ spectrum reported for aplysamine 4 differed to our compound (Table 3 ) in the following ways: In aplysamine 4 , the aromatic protons from ring $\mathrm{A}$ and $\mathrm{B}$ are all at $\delta_{\mathrm{H}} \sim 7.44$. We found two different environments for the aromatic ring protons, where $\mathrm{H}-2$ were at $\delta_{\mathrm{H}} 7.44$ but $\mathrm{H}-20$ were at 7.55. This could be attributed to the use of different solvents but what was also different was the chemical shift of the ethyl and propyl-chain carbons. In aplysamine 4 the propyl group terminated with an ammonium ion $(\mathrm{C}-20=39.0 \mathrm{ppm})$ whereas in our compound, this carbon was at $36.2 \mathrm{ppm}$. Similarly the carbon shifts for the ethyl group did not match those of aplysamine 4 . 
Table 3. NMR (DMSO- $d_{6}, 600 \mathrm{MHz}$ ) data for new bromotyrosine aplysamine 8 (2).

\begin{tabular}{|c|c|c|c|c|c|c|}
\hline Position & $\boldsymbol{\delta}_{\mathbf{C}}$ & Type & $\delta_{\mathrm{H}}, \mathbf{m}(J$ in $\mathbf{H z})$ & COSY (H no.) & ${ }^{1} \mathrm{H}-{ }^{13} \mathrm{C}$ HMBC (C no.) & ROESY (H no.) \\
\hline 1 & 136.3 & $\mathrm{C}$ & - & & & \\
\hline 2 & 132.9 & $\mathrm{CH}$ & $7.44 \mathrm{~s}$ & 7 & 3,4 & 7 \\
\hline 3 & 117.1 & $\mathrm{C}$ & - & & & \\
\hline 4 & 151.8 & $\mathrm{C}$ & - & & & \\
\hline 6 & 60.4 & $\mathrm{CH}_{3}$ & $3.75 \mathrm{~s}$ & & 4 & \\
\hline 7 & 27.9 & $\mathrm{CH}_{2}$ & $3.76 \mathrm{~s}$ & 2 & $1,2,8,11$ & 2 \\
\hline 8 & 151.0 & $\mathrm{C}$ & - & & & \\
\hline 10 & - & $\mathrm{OH}$ & $12.02 \mathrm{~s}$ & & $8(w)^{a}$ & \\
\hline 11 & 163.0 & $\mathrm{C}$ & - & & & \\
\hline 13 & - & $\mathrm{NH}$ & $8.12 \mathrm{t}(6.0)$ & 14 & 14 & $7,14,16,15(\mathrm{w})$ \\
\hline 14 & 36.2 & $\mathrm{CH}_{2}$ & $3.38 \mathrm{~m}$ & 13,15 & $11,15,16$ & 15,16 \\
\hline 15 & 29.6 & $\mathrm{CH}_{2}$ & $1.96 \mathrm{~m}$ & 14,16 & 14,16 & $13(\mathrm{w}), 14,16$ \\
\hline 16 & 71.3 & $\mathrm{CH}_{2}$ & $3.88 \mathrm{t}(6.4)$ & 15 & 14,15 & 14,15 \\
\hline 18 & 151.3 & $\mathrm{C}$ & - & & & \\
\hline 19 & 117.6 & $\mathrm{C}$ & - & & & \\
\hline 20 & 133.2 & $\mathrm{CH}$ & $7.55 \mathrm{~s}$ & & $18,19,22$ & 22,23 \\
\hline 21 & 136.8 & $\mathrm{C}$ & - & & & \\
\hline 22 & 31.5 & $\mathrm{CH}_{2}$ & $2.81 \mathrm{t}(7.4)$ & & $20,21,23$ & 20,23 \\
\hline 23 & 39.4 & $\mathrm{CH}_{2}$ & $3.05 \mathrm{~m}$ & 22,24 & 21(w) & $20,22,24$ \\
\hline 24 & - & $\mathrm{NH}_{3}$ & $7.81 \mathrm{bs}$ & 23 & - & 23 \\
\hline
\end{tabular}

The ${ }^{13} \mathrm{C}$ NMR spectrum of our compound indicated the presence of 21 carbons, one $O$-methyl ( $\delta$ 60.4), six methylenes $(\delta 71.3,39.4,36.2,31.5,29.6,27.9)$, four $\mathrm{sp}^{2}$ methines $(\delta 133.2 \times 2,132.9 \times 2)$, nine $\operatorname{sp}^{2}$ quaternary $(\delta 151.8,151.3,151.0,136.8,136.3,117.6 \times 2,117.1 \times 2)$ and one amide carbonyl $(\delta$ 163.0). All protonated carbons were assigned by HSQC experiment. Use of one and two-dimensional NMR data (Table 3) enabled the construction of three substructures (Figure 5). Inspection of ${ }^{1} \mathrm{H},{ }^{13} \mathrm{C}$, and ${ }^{1} \mathrm{H}-{ }^{1} \mathrm{H}$ COSY NMR spectra suggested that the following proton signals belonged to substructure A: $\delta_{\mathrm{H}} 12.02$ (oxime), 7.44 ( $\mathrm{sp}^{2}$ methine), 3.76 ( $\mathrm{sp}^{3}$ methine) and 3.75 (OMe). HMBC correlations from $\mathrm{H}-2$ to $\mathrm{C}-2, \mathrm{C}-3, \mathrm{H}-6$ to $\mathrm{C}-4$, and $\mathrm{H}-7 \mathrm{a} / \mathrm{b}$ to $\mathrm{C}-8$ and $\mathrm{C}-11$ provided good evidence for the oxime-tyrosine unit $\mathbf{A}$. The connection between substructures $\mathbf{A}$ and $\mathbf{B}$ was obtained by HMBC correlations from $\mathrm{H}-$ $7 \mathrm{a} / \mathrm{b}$ to carbonyl $\mathrm{C}-11$ and from the amide proton $\mathrm{H}-13$ to oxime carbon $\mathrm{C}-8$. C-8 and C-11 could be easily distinguished by their typical chemical shifts as reported in the literature [51]. The geometry of the oxime was determined as $E$ from the up-field ${ }^{13} \mathrm{C}$ chemical shift of $\mathrm{C}-7\left(\delta_{\mathrm{C}} 27.9\right), c . f$. $\delta_{\mathrm{C}} 35.7$ for 
$Z$-oximes as observed in (E, Z)-N,N'-bis-[3-(3'-bromo-4'-hydroxyphenyl)-2-oximidopropionyl] cystamine [4].

The amide proton $\left(\delta_{\mathrm{H}} 8.12\right)$ showed coupling to a methylene $\left(\delta_{\mathrm{H}} 3.38\right)$ assigned to $\mathrm{H}-14$. Further COSY correlations to $\delta_{\mathrm{H}} 1.96$, and then to $\delta_{\mathrm{H}} 3.88$ supported the assumption that substructure $\mathbf{B}$ was an amide unit connected to a propyl chain, attached to an oxygen (H-16 3.88 ppm; C-16 71.3 ppm from HSQC), which could only be explained by attachment to unit $\mathrm{C}$ via an ether linkage. Indeed, a weak correlation between C-18 (151.3 ppm) and H-16 was observed in the HMBC spectrum (Figure 6) and provided strong evidence for the assigned structure.

A

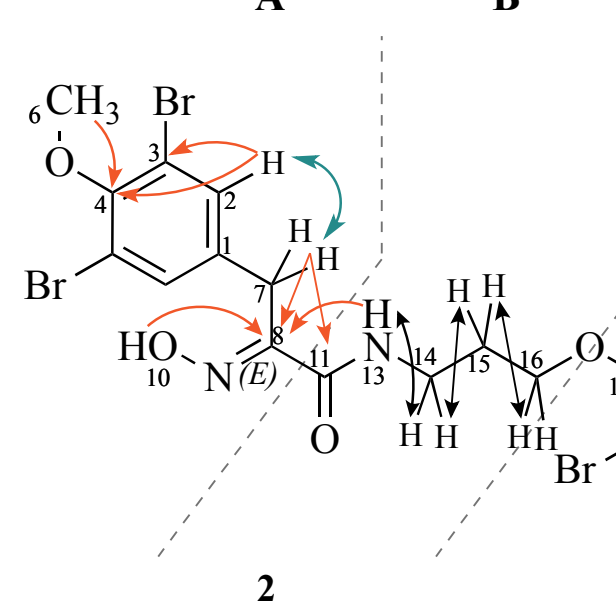

C (Colours: red (HMBC), green (ROESY), black (COSY)).

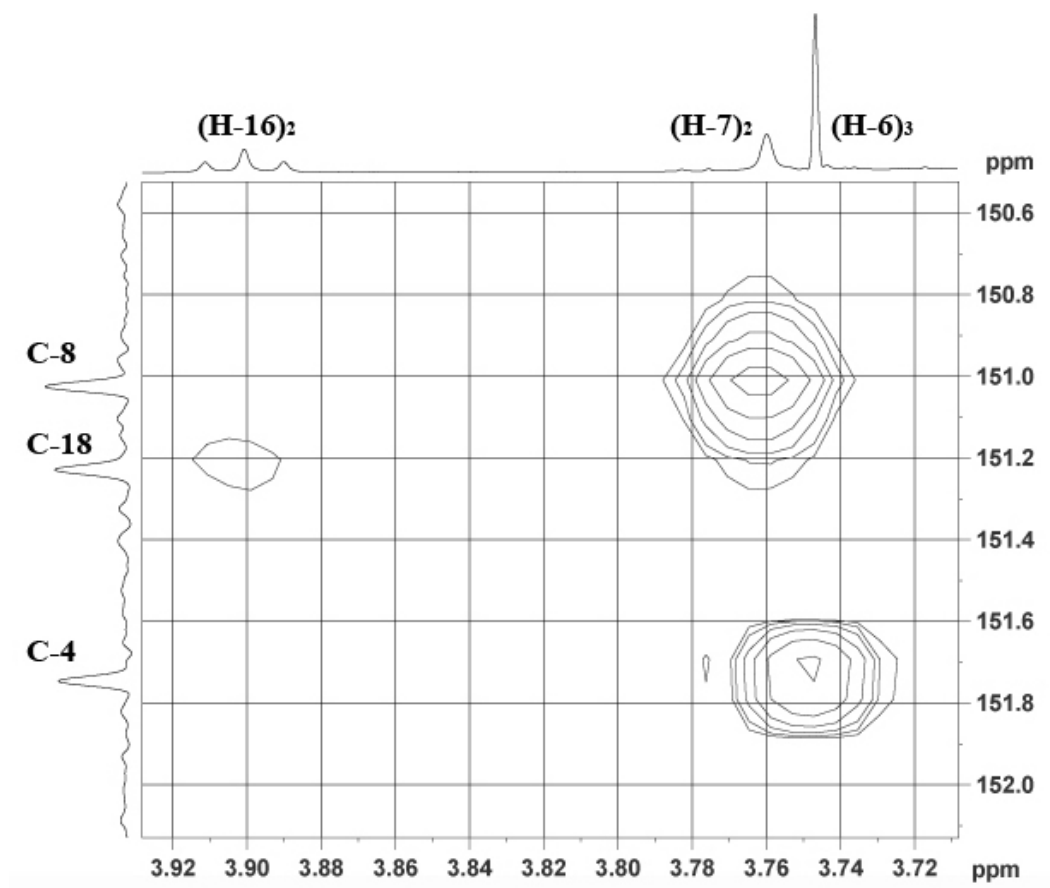

Figure 6. Selected HMBC correlations found in the unknown bromotyrosine (2; DMSO- $d 6,600 \mathrm{MHz}$ ). A weak correlation between H-16 ( $\delta$ 3.88) and C-18 ( $\delta$ 151.3) indicates the link of substructures $\mathrm{B}$ and $\mathrm{C}$. 
The signal at $\delta_{\mathrm{H}} 7.55(\mathrm{H}-20)$ showed HMBC correlations to $\mathrm{sp}^{2}$ quaternary carbons (C-18, C-19) and a ROESY correlation to a methylene at $\delta_{\mathrm{H}} 2.81 / \delta_{\mathrm{C}} 31.5$, consistent with attachment of an alkyl group directly to the aromatic ring, in support of substructure C. Direct coupling of $\delta_{\mathrm{H}} 2.81$ to $\delta_{\mathrm{H}} 3.05$, and of $\delta_{\mathrm{H}} 3.05$ to the primary amine protons at $\delta_{\mathrm{H}} 7.80$ were in good accordance to literature values [51] for a tyramine unit. Aplysamine 8 is thus an isomer of aplysamine 4 and considering the similarity in structure to aplysamines $1-7$, no new name is required for this compound.

Putting the pieces together, we conclude that this is a new brominated tyrosine derivative (2) and, due to the similarities with previously described aplysamines $1-7$, shall be named aplysamine 8 .

Compounds 1-8 were bioassayed against E. coli and $S$. aureus (MTT microdilution assay; Supplementary Information). Only aplysamine 8 (2) was found to have any notable activity (MIC $125 \mu \mathrm{g} / \mathrm{mL}$ against $E$. coli and $31 \mu \mathrm{g} / \mathrm{mL}$ against $S$. aureus) c.f. ampicillin $1.1 \mu \mathrm{g} / \mathrm{mL}$ against $S$. aureus. Hexadellin (6), aplysamine 2 (7) and 16-debromoaplysamine 4 (8) had mild activity against $S$. aureus $(125-250 \mu \mathrm{g} / \mathrm{mL})$. While the MTT and disc diffusion assays are not directly comparable, the high antibacterial activity observed for the crude extract was not reflected in the bioassay of individual metabolites. This may be due to a cumulative effect of many weak antibiotics, synergistic or contingent effects as has previously been noted for other natural products [53].

Although opisthobranchs of the genus Tylodina are found in distant regions, they are exclusively associated with sponges of the order Verongida (in particular the family Aplysinellidae) [39]. Tylodina corticalis typically feed on the genus Pseudoceratina [54]. It has also been shown, that Tylodina spp accumulate the secondary metabolites (bromotyrosine alkaloids) from their prey, sequestered and utilised as feeding deterrents for themselves and their eggs $[38,39,55,56]$.

Returning to the apparent lack of similarity between the metabolites positively identified from the sponge and those tentatively identified from $T$. corticalis, firstly it should be noted that the major difference is that many compounds found at high concentrations in the sponge were not found in the mollusc. This is, however, typically what is observed with other spongiverous molluscs such as nudibranchs, for example [25]. Next, four of the eight major compounds from the sponge were detected in the mollusc, albeit at a lower level and two of the minor/trace metabolites from the sponge were also detected in the mollusc at much higher relative concentrations. The notable difference is the high concentrations of purealidin $\mathrm{T}$ and purpuramine $\mathrm{J}$, which were not observed in the sponge extract at all despite a careful search. However, purealidin $\mathrm{T}$ is the $\mathrm{N}$-oxide of purealidin $\mathrm{Q}$ and purpuramine $\mathrm{J}$ is the $\mathrm{N}$-oxide of aplysamine 2, a major alkaloid from the sponge. Taken together these observations suggest that the sponge metabolites are certainly accumulated on a selective basis (purealidin P/Q) but also that the mollusc might be modifying the sponge metabolites (purealidin $\mathrm{T}$, purpuramine $\mathrm{J}$ ) to $\mathrm{N}$-oxides. Many cases of modification of sponge metabolites by predatory molluscs have previously been reported [57]. Certainly, the major metabolites isolated from $T$. corticalis are $N$-oxides closely related to compounds found in the sponge (Figure 7). 

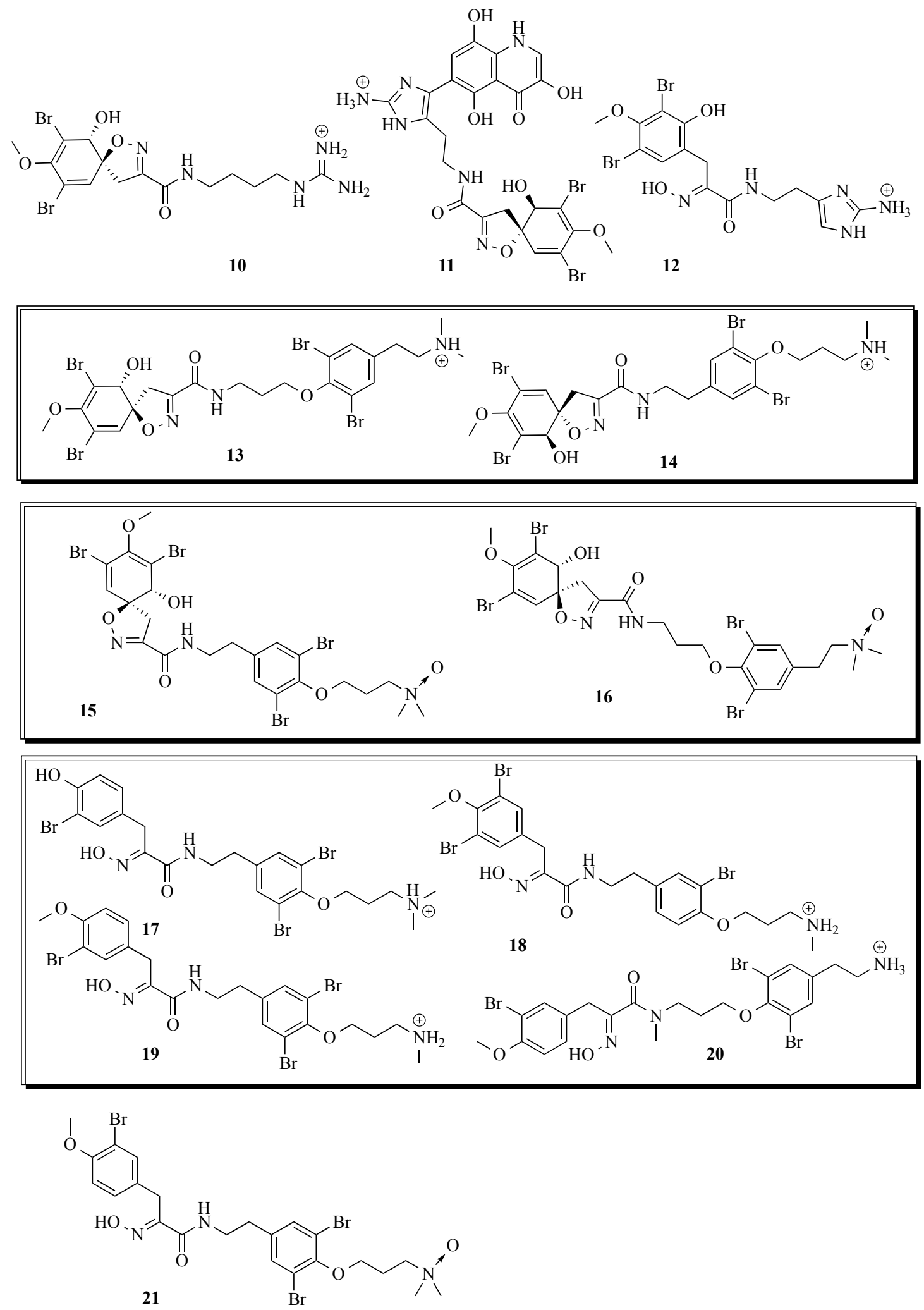

Figure 7. Bromotyrosine derivatives tentatively identified from the ethyl acetate extracts of $P$. purpurea and T. corticalis based on UV and HR-MS analysis. The boxed structures are possible isomeric forms present. Stereochemistry shown as reported in the literature. 


\section{Experimental Section}

\subsection{General Experimental Procedures}

${ }^{1} \mathrm{H}$ NMR and ${ }^{13} \mathrm{C}$ NMR spectra were recorded in $5 \mathrm{~mm}$ Pyrex tubes on a Bruker Avance DPX-400 $400 \mathrm{MHz}$ or DRX-600K $600 \mathrm{MHz}$ spectrometer. All spectra were obtained at $25{ }^{\circ} \mathrm{C}$, processed using Bruker Topspin 1.3 and referenced to residual solvent (DMSO- $d_{6} 2.50 / 39.52 \mathrm{ppm}$ ). Infrared spectra were taken on a Perkin Elmer paragon 1000PC FTIR spectrometer, or Nicolet iS10 FT-IR Spectrometer (Thermo Scientific, Scorsby, Australia). UV measurements were performed on a NanoDrop 2000 UV-Vis-Spectrophotometer (Thermo Scientific, Scorsby, Australia). The specific optical rotation was measured on a Jasco P-1010 Polarimeter (Jasco, Tokyo, Japan). Low resolution mass spectrometry was performed by electrospray ionisation (ESI) MS in positive polarity mode on a Shimadzu LC-20A prominence system coupled to a LCMS-2010 EV mass spectrometer using LCMSsolution 3.21 software. LC-MS experiments were carried out on a Gemini C18 column (Phenomenex, Sydney, Australia) $150 \times 2 \mathrm{~mm}, 110 \AA$, $3 \mu \mathrm{m}$. High resolution-LC-MS experiments were carried out on a Thermo Orbitrap Elite mass spectrometer with Easy Spray source. The samples were loaded on a C18 trap column (Acclaim, Pepmap 100, $75 \mu \mathrm{m} \times 2 \mathrm{~cm}$, nanoviper, C18, $3 \mu \mathrm{m}, 100 \AA$ ) and switched online to the analytical column (Thermo, Easy Spray column, PepMap C18 column RSLC, $\mathrm{C} 18,2 \mu \mathrm{m}, 100 \AA, 50 \mu \mathrm{m} \times 15 \mathrm{~cm}$ ) after desalting. Samples were analysed in positive polarity mode using XCalibur2.2 software.

HPLC separations were achieved on a Shimadzu 10AD-VP system running Class-VP 7.4 SP1 software. Analytical and preparative HPLC were performed on Gemini C18 HPLC columns (Phenomenex, Sydney, Australia): Gemini-NX C18 $250 \times 4.6 \mathrm{~mm}, 110 \AA$, $5 \mu \mathrm{m}$ and Gemini-NX C18 $150 \times 21.2 \mathrm{~mm}, 110 \AA, 5 \mu \mathrm{m}$ respectively. TLC was performed with Merck Kieselgel $60 \mathrm{~F}_{254}$ plates with viewing under ultraviolet light $(254 \mathrm{~nm}$ and $365 \mathrm{~nm})$ and/or by heating, after treatment with $10 \%$ phosphomolybdic acid in ethanol. Flash column chromatography was performed on silica gel (60 $\AA$ 0.040-0.063 mm, 230-400 mesh ASTM from Merck).

\subsection{Animal Material}

The sponge (654 g) was collected by hand at Jervis Bay, NSW, Australia (S 35 $08^{\prime} 07^{\prime \prime}$, E 150 43'33", at 1-4 m depth) under New South Wales Department of Primary Industries collecting permitNo. P08/0006-1.1. The samples were frozen upon collection and stored at $-20{ }^{\circ} \mathrm{C}$. It was identified as Pseudoceratina purpurea Carter (phylum Porifera, class Demospongiae, order Verongida, family Aplysinellidae). A voucher specimen (JB-S07) was prepared according to Hooper [58] and deposited at the Department of Chemistry and Biomolecular Sciences, Macquarie University. The opisthobranch Tylodina corticalis (Tate) was found feeding on the sponge Pseudoceratina purpurea. One individual was separated from the sponge, frozen at $-20{ }^{\circ} \mathrm{C}$ in the field and stored at $-80{ }^{\circ} \mathrm{C}$ in the laboratory. 


\subsection{Bioassays}

Detailed descriptions of the bioassay-guided fractionation, as well as protocols for the disc diffusion and MTT assay can be found in the Supplementary Information.

\subsection{Extraction and Isolation}

The frozen sponge $(654 \mathrm{~g})$ was homogenised in distilled ethanol $(4 \times 1000 \mathrm{~mL})$ and the combined ethanol extracts filtered through celite and evaporated to approximately $1000 \mathrm{~mL}$. An aliquot $(20 \mathrm{~mL})$ was, freeze dried and stored at $-80{ }^{\circ} \mathrm{C}$. The remaining solution was partitioned against petroleum ether $(3 \times 500 \mathrm{~mL})$, ethyl acetate $(5 \times 500 \mathrm{~mL})$, and 1-butanol $(3 \times 200 \mathrm{~mL})$ to yield $0.9076 \mathrm{~g}, 6.5420 \mathrm{~g}$, and $0.2241 \mathrm{~g}$ of crude extracts respectively. The crude ethyl acetate extract $(3.5 \mathrm{~g})$ was subjected to gel permeation chromatography (Sephadex LH-20; 1:1 chloroform:methanol) and fractions 9-22, containing all the natural products were combined. The resulting dark residue (1.66 g) was purified by HPLC (preparative C18 column, $9.99 \mathrm{~mL} / \mathrm{min}$, gradient from $18 \%$ to $40 \%$ acetonitrile:water: $0.05 \%$ TFA over $40 \mathrm{~min})$.

(+)-Ceratinadin D (1): Unstable brown amorphous solid (4.5 mg; $0.011 \%$ of wet weight). $[\alpha]_{\mathrm{D}}^{20}$ $+52^{\circ}$ (c 0.45, MeOH). $\lambda_{\max }(\mathrm{MeOH}) 234,276,337 \mathrm{~nm}$. $v_{\max }$ (neat film) $3420(\mathrm{~m}), 3380(\mathrm{~m}), 3290(\mathrm{~m})$, 1677 (s), 1432 (s), 1202 (d), 1135 (s), 1047 (s), 1025 (br), 802 (s), 764 (s), 722 (s) cm ${ }^{-1} .{ }^{1} \mathrm{H}-\mathrm{NMR}$ (600 MHz, DMSO-d6) $\delta 14.3$ (bs, H-12'), 12.15 (bs, H-23), 11.93 (bs, H-21), 11.76 (d, $J=6.4$ Hz, H-1'), 10.25 (bs, H-13'), 8.93 (bs, H-11'), 8.51 (t, $J=5.8 \mathrm{~Hz}, \mathrm{H}-16), 7.28$ (bs, (H-25)2), 7.64 (d, $\left.J=6.4 \mathrm{~Hz}, \mathrm{H}-2^{\prime}\right), 6.83$ (s, H-8'), 6.54 (s, H-5), 6.36 (d, J=7.9 Hz, H-9), 3.90 (d, J=7.6 Hz, H-1), 3.63 (s, OMe), 3.59 (d, $J=3.6 \mathrm{~Hz}, \mathrm{H}-10 \mathrm{a}), 3.15$ (d, $J=3.6 \mathrm{~Hz}, \mathrm{H}-10 \mathrm{~b}), 3.13$ (m, (H-17)2), 2.51 (s, (H-19)2), $1.73(\mathrm{~m},(\mathrm{H}-18) 2) .{ }^{13} \mathrm{C}-\mathrm{NMR}\left(150 \mathrm{MHz}, \mathrm{DMSO}-d_{6}\right) \delta 173.2\left(\mathrm{C}-4^{\prime}\right), 158.9$ (C-14), 154.5 (C-11), 149.6 (C-6'), 147.2 (C-3), 146.6 (C-22), 139.9 (C-3'), 137.4 (C-9'), 131.2 (C-5), 128.9 (C-10'), 124.2 (C-2'), 122.4 (C-20), 120.9 (C-2), 117.8 (C-24), 113.7 (C-8'), 113.1 (C-4), 112.6 (C-5'), 103.7 (c-7'), 90.1 (C-6), 73.6 (C-1), 59.7 (C-8), 39.0 (C-10), 38.2 (C-17), 28.1 (C-18), 21.6 (C-19). Mass spectrum $(\mathrm{ESI}+$ ) $\mathrm{m} / \mathrm{z}$ : isotopic cluster 695:697:699 (in ratio 1:2:1). (HRESI+) Found $\mathrm{m} / \mathrm{z}:$ 695.0067, $\mathrm{C}_{25} \mathrm{H}_{25} \mathrm{~N}_{6} \mathrm{O}_{8}{ }^{79} \mathrm{Br}_{2}$ requires 695.0101 .

Aplysamine 8 (2): Light yellow solid (0.9 mg; 0.002\% of wet weight). $\lambda_{\max }(\mathrm{MeOH}) 209,278 \mathrm{~nm}$. $v_{\max }($ neat film) $3572(\mathrm{~m}), 3187(\mathrm{~m}), 3061(\mathrm{~m}), 2930(\mathrm{~m}), 1721$ (m), 1685 (s) 1672 (m), 1642 (m), 1631 (m), 1546 (m), 1422 (s), 1258 (s), 1201 (br), 1001 (s), 835 (s), 734 (s), 721 (s) cm ${ }^{-1}$. ${ }^{1} \mathrm{H}-\mathrm{NMR}$ (400 MHz, DMSO-d6) $\delta 12.02$ (s, H-10), 8.12 (t, $J=6.0 \mathrm{~Hz}, \mathrm{H}-13), 7.81$ (bs, (H-24)2), 7.55 (s, (H-20)2), $7.44(\mathrm{~s},(\mathrm{H}-2) 2), 3.88$ (t, $J=6.4 \mathrm{~Hz},(\mathrm{H}-16) 2), 3.76(\mathrm{~s},(\mathrm{H}-7) 2), 3.75$ (s, OMe), 3.38 (m, (H-14)2), $3.05(\mathrm{~m},(\mathrm{H}-23) 2), 2.81(\mathrm{t}, J=7.4 \mathrm{~Hz},(\mathrm{H}-22) 2), 1.96\left(\mathrm{~m},(\mathrm{H}-15)_{2}\right) .{ }^{13} \mathrm{C}-\mathrm{NMR}(100 \mathrm{MHz}$, DMSO-d6) $\delta 163.0$ (C-11), 151.8 (C-4), 151.3 (C-18), 151.0 (C-8), 136.8 (C-21), 136.3 (C-1), 133.2 ((C-20)2), 132.9 ((C-2)2), 117.6 ((C-19)2), 117.1 ((C-3)2), 71.3 (C-16), $60.4(\mathrm{OMe}), 27.9$ (C-7), 39.4 (C-23), 36.2 (C-14), 31.5 (C-22), 29.6 (C-15). Mass spectrum (ESI+) $\mathrm{m} / z$ : isotopic cluster 698:700:702:704:706 (in ratio 1:4:6:4:1). (HRESI+) Found 697.8527, $\mathrm{C}_{21} \mathrm{H}_{24}{ }^{79} \mathrm{Br}_{4} \mathrm{~N}_{3} \mathrm{O}_{4}$ requires 697.8500.

(-)-Pseudoceratinin A (3): [45] Unstable light yellow solid (15.4 mg; 0.038\% of wet weight). $[\alpha]_{\mathrm{D}}^{20}-154^{\circ}\left(c\right.$ 0.5, MeOH) Lit. $-158^{\circ} .{ }^{1} \mathrm{H}-\mathrm{NMR}\left(600 \mathrm{MHz}, \mathrm{DMSO}-d_{6}\right) \delta 12.10$ (s, NH-13), 11.80 (s, 
NH-12), 8.60 (t, $J=8.6 \mathrm{~Hz}, \mathrm{NH}-9), 7.40$ ( $\left.\mathrm{NH}_{2}-14\right), 6.59$ (s, H-13), 6.55 (bs, C1-OH), 6.54 (s, H-5), 3.89 (s, H-1), 3.62 (s, OMe), 3.59 (d, $J=18.2 \mathrm{~Hz}, \mathrm{H}-7 \mathrm{a}), 3.35$ (q, $\left.J=6.4 \mathrm{~Hz},(\mathrm{H}-10)_{2}\right), 3.17$ (d, $J=18.1 \mathrm{~Hz}, \mathrm{H}-7 \mathrm{~b}), 2.59$ (t, $\left.J=6.5 \mathrm{~Hz},(\mathrm{H}-11)_{2}\right) .{ }^{13} \mathrm{C}-\mathrm{NMR}\left(150 \mathrm{MHz}, \mathrm{DMSO}-d_{6}\right) \delta 159.5(\mathrm{C}-9), 154.9$ (C-8), 147.6 (C-3), 147.5 (C-14), 131.7 (C-5), 124.7 (C-12), 121.3 (C-2), 113.6 (C-4), 109.9 (C-13), 90.7 (C-6), 74.1 (C-1), $60.1(\mathrm{MeO}), 39.5$ (C-7), 37.8 (C-10), 24.8 (C-11). Mass spectrum (ESI+) $m / z$ : isotopic cluster 490:492:494 (in ratio 1:2:1).

(+)-Aerophobin 2 (4): [46] Off-white solid (9.1 mg; $0.022 \%$ of wet weight). $[\alpha]_{\mathrm{D}}^{20}+128^{\circ}(c 0.55$, $\mathrm{MeOH}$ ), Lit. [46] +139 $.{ }^{1} \mathrm{H}-\mathrm{NMR}\left(600 \mathrm{MHz}, \mathrm{DMSO}-d_{6}\right) \delta 12.11$ (s, NH-14), 11.70 (s, NH-13), 8.57 (t, $J=5.9$ Hz, NH-9), 7.37 (s, NH2-15), 6.57 (s, H-14), 6.56 (s, H-5), 3.90 (s, H-1), 3.63 (s, OMe), 3.60 (d, $J=17.8 \mathrm{~Hz}, \mathrm{H}-7 \mathrm{a}), 3.18$ (d, $J=17.8 \mathrm{~Hz}, \mathrm{H}-7 \mathrm{~b}), 3.16$ (q, $\left.J=6.6 \mathrm{~Hz},(\mathrm{H}-10)_{2}\right), 2.39$ (t, $J=7.4 \mathrm{~Hz}$, (H-12) $\left.)_{2}\right), 1.69$ (m, (H-11)2). ${ }^{13} \mathrm{C}-\mathrm{NMR}\left(150 \mathrm{MHz}, \mathrm{DMSO}-d_{6}\right) \delta 159.5$ (C-9), 155.0 (C-8), 147.6 (C-3), 147.3 (C-15), 131.7 (C-5), 126.8 (C-13), 121.3 (C-2), 113.6 (C-4), 109.3 (C-14), 90.7 (C-6), 74.1 (C-1), $60.1(\mathrm{MeO}), 39.8$ (C-7), 38.5 (C-10), 27.8 (C-11), 22.0 (C-12). Mass spectrum (ESI+) m/z: isotopic cluster 504:506:508 (in ratio 1:2:1).

(-)-Hexadellin A (5): [47] Slight-pink solid (8.1 mg; $0.020 \%$ of wet weight). $[\alpha]_{\mathrm{D}}^{20}-19^{\circ}(c 0.5$, $\mathrm{MeOH}) .{ }^{1} \mathrm{H}-\mathrm{NMR}\left(400 \mathrm{MHz}, \mathrm{DMSO}-d_{6}\right) \delta 8.55$ (t, $\left.J=5.6 \mathrm{~Hz}, \mathrm{H}-10\right), 7.82(\mathrm{bs},(\mathrm{H}-20) 2), 7.57$ (bs, (H-16)2), 6.56 (bs, H-5), 6.36 (bs, C1-OH), 3.94 (t, $\left.J=6.2 \mathrm{~Hz},(\mathrm{H}-13)_{2}\right), 3.90$ (s, H-1), 3.62 (s, OMe), 3.58 (d, $J=18.2 \mathrm{~Hz}, \mathrm{H}-7 \mathrm{a}), 3.19$ (d, $J=18.2 \mathrm{~Hz}, \mathrm{H}-7 \mathrm{~b}), 3.38$ (m, H-11), 3.05 (m, (H-19)2), 2.81 (t, $\left.J=7.2 \mathrm{~Hz},(\mathrm{H}-18)_{2}\right), 1.98$ (m, (H-12)2). ${ }^{13} \mathrm{C}-\mathrm{NMR}\left(100 \mathrm{MHz}, \mathrm{DMSO}-d_{6}\right) \delta 159.4$ (C-9), $155.0(\mathrm{C}-8)$, 151.7 (C-14), 147.6 (C-3), 137.3 (C-17), 133.7 (C-16), 131.7 (C-5), 121.3 (C-2), 118.1 (C-15), 113.6 (C-4), 90.7 (C-6), 74.1 (C-1), 71.7 (C-13), 60.1 (OMe), 39.0 (C-7), 39.0 (C-19), 36.7 (C-11), 32.0 (C-18), 29.9 (C-12). Mass spectrum (ESI+) $m / z$ : isotopic cluster 714:716:718:720:722 (in ratio 1:4:6:4:1).

Aplysamine 2 (6): [48] Light brown solid (9.0 mg; 0.022\% of wet weight). ${ }^{1} \mathrm{H}-\mathrm{NMR}$ (400 MHz, DMSO- $\left.d_{6}\right) \delta 11.90(\mathrm{~s}, \mathrm{~N}-\mathrm{OH}), 8.05$ (t, $\left.J=6.0 \mathrm{~Hz}, \mathrm{NH}-9\right), 7.48$ (s, H-13 and H-17), 7.37 (d, $J=2.0 \mathrm{~Hz}$, H-2), 7.11 (dd, $J=8.5 \mathrm{~Hz}, 2.1 \mathrm{~Hz}, \mathrm{H}-6), 6.97$ (d, $J=8.5 \mathrm{~Hz}, \mathrm{H}-5), 3.96$ (t, $\left.J=5.9 \mathrm{~Hz},(\mathrm{H}-18)_{2}\right), 3.78$ (s, OMe), $3.70(\mathrm{~s},(\mathrm{H}-7) 2), 3.35$ (m, (H-10)2), 3.34 (m, (H-20)2), 2.83 (s, $\left(\mathrm{NMe}_{2}\right), 2.72$ (t, J=7.0 Hz, $\mathrm{H}-11), 2.18$ (m, (H-19)2). ${ }^{13} \mathrm{C}-\mathrm{NMR}\left(100 \mathrm{MHz}, \mathrm{DMSO}-d_{6}\right) \delta 163.3$ (C-9), 153.0 (C-4), 151.8 (C-8), 150.2 (C-15), 139.4 (C-12), 133.1 (C-13 and C-17), 133.0 (C-2), 129.2 (C-6), 117.2 (C-14 and C-16), 113.8 (C-5), 112.6 (C-3), 110.1 (C-1), 70.2 (C-18), 56.2 (OMe), $42.4\left(\mathrm{NMe}_{2}\right), 39.6$ (C-10), 39.6 (C-20), 33.4 (C-11), 27.8 (C-7), 24.8 (C-19). Mass spectrum (ESI+) $m / z$ : isotopic cluster 648:650:652:654 (in ratio 1:3:3:1).

16-Debromoaplysamine 4 (7): [49] Light brown solid (1.6 mg; 0.004\% of wet weight). ${ }^{1} \mathrm{H}-\mathrm{NMR}$ $\left(400 \mathrm{MHz}, \mathrm{DMSO}-d_{6}\right) \delta 11.98(\mathrm{~s}, \mathrm{~N}-\mathrm{OH}), 8.16$ (t, $\left.J=5.9 \mathrm{~Hz}, \mathrm{NH}-9\right), 7.77$ (s, NH), 7.47 (s, H-13), 7.45 (s, H-1 and H-5), 7.19 (dd, $J=8.4 \mathrm{~Hz}, 2.1 \mathrm{~Hz}, \mathrm{H}-17), 7.00$ (d, $J=8.4 \mathrm{~Hz}, \mathrm{H}-16), 3.99$ (t, $J=6.1 \mathrm{~Hz}$, (H-18) $)_{2}, 3.75$ (s, (H-7)2), 3.74 (s, (OMe), 3.34 (m, (H-20)2), 3.00 (t, J= $\left.7.8 \mathrm{~Hz},(\mathrm{H}-10)_{2}\right), 2.77$ (t, $J=7.7 \mathrm{~Hz},(\mathrm{H}-11) 2), 1.92(\mathrm{~m},(\mathrm{H}-19) 2) .{ }^{13} \mathrm{C}-\mathrm{NMR}(100 \mathrm{MHz}, \mathrm{DMSO}-d 6) \delta 163.3(\mathrm{C}-9), 153.6(\mathrm{C}-15)$, 151.8 (C-3), 151.1 (C-8), 136.3 (C-6), 133.0 (C-13), 132.8 (C-1, C-5), 131.2 (C-12), 129.2 (C-17), 117.0 (C-2, C-4), 113.7 (C-16), 111.3 (C-14), 66.7 (C-18), 60.2 (OMe), 39.8 (C-10), 36.1 (C-20), 31.7 (C-11), 28.7 (C-19), 27.9 (C-7). Mass spectrum (ESI+) $m / z$ : isotopic cluster 620:622:624:626 (in ratio $1: 3: 3: 1$ ). 
(-)-Purealin (8): [50] Light brown solid $\left(1.9 \mathrm{mg} ; 0.005 \%\right.$ of wet weight). $[\alpha]_{\mathrm{D}}^{20}-82^{\circ}(c 0.1$, $\mathrm{MeOH}$ ), Lit. [50] $-85^{\circ} .{ }^{1} \mathrm{H}-\mathrm{NMR}$ (400 MHz, DMSO-d6) $\delta 12.03$ (s, N-OH), 11.85 (s, NH-22), 8.57 (bs, NH-9), 8.15 (bs, NH-19), 7.44 (s, H-15 and H-15'), 7.35 (bs, NH $2-24), 6.57$ (d, $J=10.6$ Hz, H-5), 6.56 (s, H-23), 6.38 (bs, C1-OH), 3.90 (d, J=8.1 Hz, H-1), 3.75 (s, (H-17)2), 3.63 (s, (OMe), 3.61 (d, $J=18.1$ Hz, H-7a), 3.49 (m, (H-12)2), 3.38 (m, (H-10)2), 3.36 (m, (H-20)2), 3.20 (d, J=18.3 Hz, H-7b), 2.59 (m, (H-21)2), 1.97 (m, (H-11)2). ${ }^{13} \mathrm{C}-\mathrm{NMR}$ (100 MHz, DMSO-d6) $\delta 163.3$ (C-19), 158.9 (C-9), 154.5 (C-8), 151.7 (C-13), 151.0 (C-18), 147.1 (C-3), 136.3 (C-16), 132.9 (C-15 and C-15'), 131.3 (C-5), 124.4 (C-22), 120.8 (C-2), 117.1 (C-14 and C-14'), 113.1 (C-4), 109.2 (C-23), 90.2 (C-6), 73.6 (C-1), 69.8 (C-12), 59.4 (OMe), 39.4 (C-7), 37.3 (C-20), 36.2 (C-10), 29.4 (C-11), 27.9 (C-17), 24.5 (C-21). Mass spectrum (ESI+) $m / z$ : isotopic cluster 880:882:884:886:888 (in ratio 1:4:6:4:1).

The opisthobranch Tylodina corticalis was extracted by soaking overnight in ethanol $(5 \times 50 \mathrm{~mL})$ at $-20{ }^{\circ} \mathrm{C}$. The combined extracts $(327.6 \mathrm{mg})$ were partitioned against petroleum ether $(3 \times 30 \mathrm{~mL})$, ethyl acetate $(4 \times 30 \mathrm{~mL})$ and 1-butanol $(5 \times 30 \mathrm{~mL})$ to yield $40.1,12.0 \mathrm{mg}$, and $95.6 \mathrm{mg}$ of crude extract respectively. An aliquot (1 $\mathrm{mg})$ of the ethyl acetate extract was dissolved in $10 \%$ acetonitrile/water/0.1\% formic acid $(1 \mathrm{~mL})$ and analysed by low resolution-LC-MS (Gemini C18 column, $0.2 \mathrm{~mL} / \mathrm{min}$, gradient from $10 \%$ to $95 \%$ acetonitrile/water $/ 0.1 \%$ formic acid over $35 \mathrm{~min}$. For HR-LC-MS analysis $2 \mu \mathrm{L}$ of samples $(20 \mu \mathrm{g} / \mathrm{mL})$ were loaded on a C18 trap column. After desalting, samples were eluted over $30 \mathrm{~min}$ from $5 \%$ acetonitrile/0.1\% formic acid to $90 \%$ acetonitrile/ $0.1 \%$ formic acid at $300 \mathrm{~nL} / \mathrm{min}$.

\section{Conclusions}

This is the first report of two previously unknown brominated tyrosine derivatives (1 and 2) including a full structure analysis of these and six other compounds from Pseudoceratina purpurea. The antimicrobial activity of the isolated compounds was assessed against common human pathogens in preliminary assays and showed moderate activity for compound $\mathbf{2}$ against $S$. aureus. Seven further compounds found in the sponge or its predator, were tentatively assigned by UV and high resolution MS data.

\section{Acknowledgments}

The HR-LC-ESI-MS experiment was performed by the Australian Proteome Analysis Facility, Sydney. The authors acknowledge Xiaomin Song and for access to the Thermo Orbitrap Elite instrument.

\section{Author Contributions}

PK and MG collected the organisms. MG extracted and isolated the compounds and performed all the biological assays. Spectral data and structure elucidation were collected and analysed by MG and PK. MG drafted the manuscript and PK edited the final version and is responsible for its content.

\section{Supplementary Information}

Supplementary Information including details on the bioassays, biological material, HRMS and NMR data are available upon request. 


\section{Conflicts of Interest}

The authors declare no conflict of interest.

\section{References}

1. Harper, M.K.; Bugni, T.S.; Copp, B.R.; James, R.D.; Lindsay, B.S.; Richardson, A.D.; Schnabel, P.C.; Tasdemir, D.; vanWagoner, R.M.; Verbitski, S.M.; et al. Introduction to the chemical ecology of marine natural products. In Marine Chemical Ecology; McClintock, J.B., Baker, B.J., Eds.; CRC Press LLC: Boca Raton, FL, USA, 2001; pp. 3-69.

2. Bergquist, P.R.; Wells, R.J. Chemotaxonomy of the Porifera: The development and current status of the field. In Marine Natural Products; Scheuer, P.J., Ed.; Academic: New York, NY, USA, 1983.

3. Bergquist, P.R.; Karuso, P.; Cambie, R.C.; Smith, D.J. Sterol composition and classification of the Porifera. 3. Biochem. Syst. Ecol. 1991, 19, 17-24.

4. Arabshahi, L.; Schmitz, F.J. Brominated tyrosine metabolites from an unidentified sponge. J. Org. Chem. 1987, 52, 3584-3586.

5. Teeyapant, R.; Kreis, P.; Wray, V.; Witte, L.; Proksch, P. Brominated secondary compounds from the marine sponge Verongia aerophoba and the sponge feeding gastropod Tylodina perversa. Z. Naturforsch. C: Biosci. 1993, 48, 640-644.

6. Shaala, L.A.; Bamane, F.H.; Badr, J.M.; Youssef, D.T.A. Brominated arginine-derived alkaloids from the red sea sponge Suberea mollis. J. Nat. Prod. 2011, 74, 1517-1520.

7. Salim, A.A.; Khalil, Z.G.; Capon, R.J. Structural and stereochemical investigations into bromotyrosine-derived metabolites from southern Australian marine sponges, Pseudoceratina spp. Tetrahedron 2012, 68, 9802-9807.

8. Jang, J.-H.; van Soest, R.W.M.; Fusetani, N.; Matsunaga, S. Pseudoceratins A and B, antifungal bicyclic bromotyrosine-derived metabolites from the marine sponge Pseudoceratina purpurea. J. Org. Chem. 2007, 72, 1211-1217.

9. Kon, Y.; Kubota, T.; Shibazaki, A.; Gonoi, T.; Kobayashi, J.I.; Ceratinadins, A.-C. New bromotyrosine alkaloids from an Okinawan marine sponge Pseudoceratina sp. Bioorg. Med. Chem. Lett. 2010, 20, 4569-4572.

10. Jurek, J.; Yoshida, W.Y.; Scheuer, P.J.; Kelly-Borges, M. Three new bromotyrosine-derived metabolites of the sponge Psammaplysilla purpurea. J. Nat. Prod. 1993, 56, 1609-1612.

11. Kobayashi, J.I.; Honma, K.; Sasaki, T.; Tsuda, M.; Purealidins, J.-R. New bromotyrosine alkaloids from the Okinawan marine sponge Psammaplysilla purea. Chem. Pharm. Bull. 1995, 43, 403-407.

12. Tsukamoto, S.; Kato, H.; Hirota, H.; Fusetani, N. Ceratinamides A and B: New antifouling dibromotyrosine derivatives from the marine sponge Pseudoceratina purpurea. Tetrahedron 1996, 52, 8181-8186.

13. Compagnone, R.S.; Avila, R.; Suarez, A.I.; Abrams, O.V.; Rangel, H.R.; Arvelo, F.; Pina, I.C.; Merentes, E. 11-Deoxyfistularin-3, a new cytotoxic metabolite from the Caribbean sponge Aplysina fistularis insularis. J. Nat. Prod. 1999, 62, 1443-1444. 
14. Tabudravu, J.N.; Jaspars, M. Purealidin S and purpuramine J, bromotyrosine alkaloids from the Fijian marine sponge Druinella sp. J. Nat. Prod. 2002, 65, 1798-1801.

15. Kalaitzis, J.A.; De, A.L.P.; Hooper, J.N.A.; Quinn, R.J. Ianthesine E, a new bromotyrosine-derived metabolite from the Great Barrier Reef sponge Pseudoceratina sp. Nat. Prod. Res. 2008, 22, $1257-1263$.

16. Teruya, T.; Iwasaki, A.; Suenaga, K. 20- $N$-methylpurpuramine E: New bromotyrosine-derived metabolite from Okinawan marine sponge Pseudoceratina purpurea. Bull. Chem. Soc. Jpn. 2008, 81, 1026-1027.

17. Proksch, P.; Putz, A.; Ortlepp, S.; Kjer, J.; Bayer, M. Bioactive natural products from marine sponges and fungal endophytes. Phytochem. Rev. 2010, 9, 475-489.

18. Su, J.-H.; Chen, Y.-C.; El-Shazly, M.; Du, Y.-C.; Su, C.-W.; Tsao, C.-W.; Liu, L.-L.; Chou, Y.; Chang, W.-B.; Su, Y.-D.; et al. Towards the small and the beautiful: A small dibromotyrosine derivative from Pseudoceratina sp. sponge exhibits potent apoptotic effect through targeting IKK/NFкB signaling pathway. Mar. Drugs 2013, 11, 3168-3185.

19. Shaala, L.A.; Youssef, D.T.A.; Sulaiman, M.; Behery, F.A.; Foudah, A.I.; El Sayed, K.A. Subereamolline A as a potent breast cancer migration, invasion and proliferation inhibitor and bioactive dibrominated alkaloids from the Red Sea sponge Pseudoceratina arabica. Mar. Drugs 2012, 10, 2492-2508.

20. Niemann, H.; Lin, W.; Mueller, W.E.G.; Kobbutat, M.; Lai, D.; Proksch, P. Trimeric hemibastadin congener from the marine sponge Ianthella basta. J. Nat. Prod. 2013, 76, 121-125.

21. Tran, T.D.; Pham, N.B.; Fechner, G.; Hooper, J.N.A.; Quinn, R.J. Bromotyrosine alkaloids from the Australian marine sponge Pseudoceratina verrucosa. J. Nat. Prod. 2013, 76, 516-523.

22. Xu, M.; Andrews, K.T.; Birrell, G.W.; Tran, T.L.; Camp, D.; Davis, R.A.; Quinn, R.J. Psammaplysin $\mathrm{H}$, a new antimalarial bromotyrosine alkaloid from a marine sponge of the genus Pseudoceratina. Bioorg. Med. Chem. Lett. 2011, 21, 846-848.

23. Galeano, E.; Thomas, O.P.; Robledo, S.; Munoz, D.; Martinez, A. Antiparasitic bromotyrosine derivatives from the marine sponge Verongula rigida. Mar. Drugs 2011, 9, 1902-1913.

24. Mani, L.; Jullian, V.; Mourkazel, B.; Valentin, A.; Dubois, J.; Cresteil, T.; Folcher, E.; Hooper, J.N.A.; Erpenbeck, D.; Aalbersberg, W.; et al. New antiplasmodial bromotyrosine derivatives from Suberea ianthelliformis Lendenfeld, 1888. Chem. Biodivers. 2012, 9, 1436-1451.

25. Karuso, P. Chemical ecology of the nudibranchs. Bioorg. Mar. Chem. 1987, 1, 31-60.

26. Hao, E.; Fromont, J.; Jardine, D.; Karuso, P. Natural products from sponges of the genus Agelas - on the trail of a [2 + 2]-photoaddition enzyme. Molecules 2001, 6, 130-141.

27. Tsukamoto, S.; Kato, H.; Hirota, H.; Fusetani, N. Pseudoceratidine: A new antifouling spermidine derivative from the marine sponge Pseudoceratina purpurea. Tetrahedron Lett. 1996, 37, 1439-1440.

28. Tsukamoto, S.; Kato, H.; Hirota, H.; Fusetani, N. Pseudoceramine: An unprecedented antifouling cyanoformamide from the marine sponge Pseudoceratina purpurea. J. Org. Chem. 1996, 61, 2936-2937.

29. Fusetani, N.; Masuda, Y.; Nakao, Y.; Matsunaga, S.; van Soest, R.W.M. Three new bromotyrosine derivatives lethal to crab from the marine sponge, Pseudoceratina purpurea. Tetrahedron 2001, 57, 7507-7511. 
30. Takada, N.; Watanabe, R.; Suenaga, K.; Yamada, K.; Ueda, K.; Kita, M.; Uemura, D. Zamamistatin, a significant antibacterial bromotyrosine derivative, from the Okinawan sponge Pseudoceratina purpurea. Tetrahedron Lett. 2001, 42, 5265-5267.

31. Peng, X.; Deng, S.; Xiao, D.; Wu, H. Chemical constituents of the marine sponge Pseudoceratina purpurea from South China Sea (I). Guangzhou Huaxue 2003, 28, 1-4.

32. Peng, X.; Deng, S.; Xiao, D.; Ma, W.; Wu, H. Studies on the active constituents of the marine sponge Pseudoceratina purpurea from the South China Sea. Zhongguo Haiyang Yaowu 2004, 23, 11-13.

33. Kijjoa, A.; Bessa, J.; Wattanadilok, R.; Sawangwong, P.; Nascimento, M.S.J.; Pedro, M.; Silva, A.M.S.; Eaton, G.; van Soest, R.; Herz, W. Dibromotyrosine derivatives, a maleimide, aplysamine-2 and other constituents of the marine sponge Pseudoceratina purpurea. Z. Naturforsch. B Chem. Sci. 2005, 60, 904-908.

34. Hertiani, T.; Edrada, R.; van, S.R.W.M.; Mueller, W.E.G.; Sudarsono Proksch, P. Chemical investigation on Pseudoceratina purpurea collected from Banyuwangi Indonesia. Indonesian J. Pharm. 2009, 20, 17-26.

35. McCulloch, M.W.B.; Coombs, G.S.; Banerjee, N.; Bugni, T.S.; Cannon, K.M.; Harper, M.K.; Veltri, C.A.; Virshup, D.M.; Ireland, C.M. Psammaplin A as a general activator of cell-based signaling assays via HDAC inhibition and studies on some bromotyrosine derivatives. Biorg. Med. Chem. 2009, 17, 2189-2198.

36. Faulkner, D.; Ghiselin, M. Chemical defense and evolutionary ecology of dorid nudibranchs and some other opisthobranch gastropods. Mar. Ecol. 1983, 13, 295-301.

37. Ebel, R.; Marin, A.; Proksch, P. Organ-specific distribution of dietary alkaloids in the marine opisthobranch Tylodina perversa. Biochem. Syst. Ecol. 1999, 27, 769-777.

38. Thoms, C.; Ebel, R.; Hentschel, U.; Proksch, P. Sequestration of dietary alkaloids by the spongivorous marine mollusk Tylodina perversa. Z. Naturforsch. C: Biosci. 2003, 58, 426-432.

39. Thoms, C.; Ebel, R.; Proksch, P. Sequestration and possible role of dietary alkaloids in the sponge-feeding mollusk Tylodina perversa. Prog. Mol. Subcell. Biol. 2006, 43, 261-275.

40. Ciminiello, P.; Fattorusso, E.; Forino, M.; Magno, S.; Pansini, M. Chemistry of verongida sponges. VIII. Bromo compounds from the Mediterranean sponges Aplysina aerophoba and Aplysina cavernicola. Tetrahedron 1997, 53, 6565-6572.

41. Encarnacion, R.D.; Sandoval, E.; Malmstrom, J.; Christophersen, C. Calafianin, a bromotyrosine derivative from the marine sponge Aplysina gerardogreeni. J. Nat. Prod. 2000, 63, 874-875.

42. Fendert, T.; Wray, V.; van Soest, R.W.M.; Proksch, P. Bromoisoxazoline alkaloids from the Caribbean sponge Aplysina insularis. Z. Naturforsch. C: Biosci. 1999, 54, 246-252.

43. Venkateswarlu, Y.; Rao, M.R.; Venkatesham, U. A new dibromotyrosine-derived metabolite from the sponge Psammaplysilla purpurea. J. Nat. Prod. 1998, 61, 1388-1389.

44. Cimino, G.; de Rosa, S.; de Stefano, S.; Spinella, A.; Sodano, G. The zoochrome of the sponge Verongia aerophoba ("Uranidine"). Tetrahedron Lett. 1984, 25, 2925-2928.

45. Benharref, A.; Pais, M.; Debitus, C. Bromotyrosine alkaloids from the sponge Pseudoceratina verrucosa. J. Nat. Prod. 1996, 59, 177-180.

46. Cimino, G.; Rosa, S.D.; Stefano, S.D.; Self, R.; Sodano, G. The bromo-compounds of the true sponge Verongia aerophoba. Tetrahedron Lett. 1983, 24, 3029-3032. 
47. Morris, S.A.; Andersen, R.J. Nitrogenous metabolites from the deep water sponge Hexadella $\mathrm{sp.}$ Can. J. Chem. 1989, 67, 677-681.

48. Xynas, R.; Capon, R.J. Two new bromotyrosine-derived metabolites from an Australian marine sponge, Aplysina sp. Aust. J. Chem. 1989, 42, 1427-1433.

49. Pakrashi, S.C.; Achari, B.; Dutta, P.K.; Chakrabarti, A.K.; Giri, C.; Saha, S.; Basa, S.C. Marine products from bay of Bengal: Constituents of the sponge. Tetrahedron 1994, 50, 12009-12014.

50. Nakamura, H.; Wu, H.; Kobayashi, J.; Nakamura, Y.; Ohizumi, Y.; Hirata, Y. Purealin, a novel enzyme activator from the Okinawan marine sponge Psammaplysilla purea. Tetrahedron Lett. 1985, 26, 4517-4520.

51. Peng, J.; Li, J.; Hamann, M.T. The marine bromotyrosine derivatives. In The Alkaloids: Chemistry and Biology; Cordell, G.A., Ed.; Academic Press: San Diego, CA, USA, 2005; Volume 61, pp. 59-262.

52. Mukai, H.; Kubota, T.; Aoyama, K.; Mikami, Y.; Fromont, J.; Kobayashi, J. Tyrokeradines A and $\mathrm{B}$, new bromotyrosine alkaloids with an imidazolyl-quinolinone moiety from a Verongid sponge. Bioorg. Med. Chem. Lett. 2009, 19, 1337-1339.

53. Gershenzon, J.; Dudareva, N. The function of terpene natural products in the natural world. Nat. Chem. Biol. 2007, 3, 408-414.

54. Willan, R.C. A review of the diets in the Notaspidea (Mollusca: Opisthobranchia). J. Malacol. Soc. Aust. 1984, 6, 125-142.

55. Thoms, C.; Schupp, P.J. Activated chemical defense in marine sponges-A case study on Aplysinella rhax. J. Chem. Ecol. 2008, 34, 1242-1252.

56. Becerro, M.A.; Turon, X.; Uriz, M.J.; Templado, J. Can a sponge feeder be a herbivore? Tylodina perversa (Gastropoda) feeding on Aplysina aerophoba (Demospongiae). Biol. J. Linn. Soc. 2003, $78,429-438$.

57. Cimino, G.; Sodano, G. Biosynthesis of secondary metabolites in marine mollusks. Top. Curr. Chem. 1993, 167, 77-115.

58. Hooper, J.N.A. "Sponguide". Guide to Sponge Collection and Identification; Queensland Museum: Brisbane, Australia, 2000.

(C) 2015 by the authors; licensee MDPI, Basel, Switzerland. This article is an open access article distributed under the terms and conditions of the Creative Commons Attribution license (http://creativecommons.org/licenses/by/4.0/). 